\title{
Nanosystems in Cosmetic Products: A Brief Overview of Functional, Market, Regulatory and Safety Concerns
}

\author{
Chiara Ferraris (D), Clara Rimicci (D), Sara Garelli, Elena Ugazio *(D) and Luigi Battaglia *(D) \\ Dipartimento di Scienza e Tecnologia del Farmaco, Università degli Studi di Torino, Via Pietro Giuria 9, \\ 10125 Turin, Italy; chiara.ferraris@unito.it (C.F.); clararimicci1996@gmail.com (C.R.); \\ saragarelli.sg@gmail.com (S.G.) \\ * Correspondence: elena.ugazio@unito.it (E.U.); luigi.battaglia@unito.it (L.B.); \\ Tel.: +39-011-670-7192 (E.U.); +39-011-670-7142 (L.B.)
}

\begin{abstract}
Nanosystems exhibit various innovative physico-chemical properties as well as a range of cosmetic functions, including increased skin retention for loaded compounds. The worldwide nano-market has therefore been consistently extensive in recent decades. This review summarizes the most important properties of nanosystems that are employed in cosmetics, including composition, functions and interactions with skin, with particular attention being paid to marketed products. Moreover, the worldwide regulatory landscape of nanomaterials used as cosmetic ingredients is considered, and the main safety concerns are indicated. In general, advanced physico-chemical characterization is preliminarily needed to assess the safety of nanomaterials for human health and the environment. However, there is currently a shortfall in global legislation as a universally accepted and unambiguous definition of a nanomaterial is still lacking. Therefore, each country follows its own regulations. Anyhow, the main safety concerns arise from the European context, which is the most restrictive. Accordingly, the poor dermal permeation of nanomaterials generally limits their potential toxic effects, which should be mainly ascribed to unwanted or accidental exposure routes.
\end{abstract}

Keywords: nanomaterials; cosmetics; dermal delivery

\section{Introduction}

The development of innovative topical delivery systems is an exciting goal for researchers and the industrial field, especially because of the claimed advantages, such as the extensive cutaneous area and the easy handling of ready-to-use products. Nevertheless, the skin forms a barrier to substances applied to its external surface. Within this context, nanotechnology can be used to modify the process of permeation/penetration of bioactive substances through the skin by controlling their release and prolonging their residence time [1]. Moreover, it ensures direct contact can be made with the stratum corneum and skin appendages, while it also protects the loaded compounds against chemical and/or physical instability. Furthermore, the delivery of bioactive agents without the need for chemical enhancers is desirable as it can help to maintain normal skin-barrier function [1]. As a result, the use of nanocarriers for skin administration is expanding.

Of the leading industrial sectors, the cosmetic sector was among the first to consider nanotechnology-based products, and it is currently a global leader in the incorporation of nanotechnologies in the development of new products [2]. In fact, a large number of nanosystems are commonly used in cosmetic formulations to encapsulate active ingredients [3]. The nanosystems employed in cosmetic products are made up of a variety of chemical compounds and compositions that are formulated in the nanometric range, and, owing to different supramolecular structures, include vesicular nanostructures (liposomes, niosomes), liquid nanoemulsions and nanoparticles [4,5]. The latter can be made up of matrixes of different origin and further divided into nanospheres (homogeneous matrices) and nanocapsules (core-shell structure). Moreover, when intended for cosmetic use, the 
final product itself can be formulated as a nanosystem (e.g., a cosmetic nanoemulsion), or, alternatively, a nanosystem can be included as a nano-ingredient in the final cosmetic product. The main targets of these innovative delivery systems for cosmetics include: improved skin retention for active ingredients, new colour elements (e.g., in lipsticks and nail polishes), transparency (e.g., in sunscreens), and long-lasting effects (e.g., in makeup). Indeed, their ultimate goal is to deliver the right amount of active ingredient to the desired parts of the body, and to attain long term stability [6]. However, although nanomaterials have aroused remarkable interest in the scientific community because of their atypical and innovative physico-chemical properties compared to bulk materials, there is distinct lack of an unambiguous and universally accepted definition of nanomaterial. The International Organization for Standardization (ISO) has defined "nanomaterial" as a "material with any external dimension in the nanoscale or having internal structure or surface structure in the nanoscale" [7], with nanoscale being defined as the size range from approximately 1-100 nm [8]. Nonetheless, these technical definitions, based on size only, may be insufficient from a risk evaluation standpoint, as they do not include other important elements that should be considered when determining whether a nanomaterial may need a more detailed assessment [9].

Indeed, cosmetic products for consumers are complex chemical matrixes. The nanosystem properties that can influence their interactions with the stratum corneum, as well as their potential deposition in furrows, appendages and deeper skin layers, include: size, shape, surface charge and properties (such as coatings or functional groups), and aggregation state. However, the vehicle in which they are suspended can have an influence as it can alter the substance's properties and affect the permeability of the stratum corneum [5]. Therefore, the interactions between nanomaterials and other components of a formulation must be investigated to ensure the final cosmetic product's performance and safety. Notably, with respect to safety, relevant concerns can be ascribed to the additional toxic effects that may arise from synergic mechanisms among ingredients that are employed as combinations and/or mixtures. Unfortunately, in some cases, similar unwanted effects cannot be adequately predicted despite the existence of toxicity data on individual ingredients.

Interestingly, the application of nanotechnology in skin care cosmetics can also promote the development of dermal (and transdermal) drug delivery. With the breakthroughs in preparation technology, quality control and mechanisms that promote permeability, it can be expected that the use of innovative nanosystems in the pharmaceutical field will increase in the near future [10]. Indeed, unlike in cosmetic products, in transdermal nanomedicines, transcutaneous permeation is a desirable phenomenon, which is governed by the same principles, and hampered by the same physiological barriers that act when a cosmetic product is applied to the skin. Therefore, the investigations that are ongoing into the mechanisms involved in the dermal permeation of nanosystems can have a relevant fall-out both in the cosmetics and the dermal/transdermal drug delivery fields. Within this concern, it should be noted that innovative nanosystems entered the cosmetic market first, and only afterwards arrived on the drug-delivery market. Generally, there is a typical time-frame between the invention of a nanosystem and its introduction onto the market. From the invention of liposomes in 1965, it took about 20 years for them to reach the cosmetics market (anti-aging product "Capture" launched by Dior in 1986) and 25 years for the first pharmaceutical product (Alveofact by Dr. Karl Thomae GmbH Germany) [11]. In fact, despite considerable effort by private pharmaceutical companies, the approval rate for novel nanomedicinal products by regulatory agencies does not exceeded $10 \%$, mainly because of safety and efficacy-profile failures during clinical studies. Anyway, cosmetic products are easier to process in terms of time and economic investment, as they do not require clinical evaluation [12,13]. However, the current regulatory demands as to the safety of nanomaterials in the cosmetics field, as well as the relevant studies performed to assess this issue, could have implications on future pharmaceutical guidelines. To this aim, it is necessary to improve the development of harmonized regulations and establish a standardized evaluation system for the assessment of the efficacy and safety of cosmetic 
nanomaterials, that, in the future, might also be applied to nano-structured pharmaceutical preparations [10].

Within this context, the present review describes the most important properties of nanosystems that are used in cosmetics, such as composition, functions and interaction with the skin, and an overview of the nano-market is also included, both for cosmetic ingredients and finished cosmetic products. Moreover, the worldwide regulatory landscape of nanomaterials for use in cosmetic products is also considered, with the main safety concerns being highlighted.

\section{Formulation and Characterization of Nanosystems Used in Cosmetics}

The most important nanosystems can be classified as [14]:

- $\quad$ OD: all dimensions fall within the nanometer scale;

- $\quad 1 D$ : with one non-nanoscale and two nanoscale dimensions;

- 2D: only one dimension in the nanometer range;

- 3D: materials with various dimensions below $100 \mathrm{~nm}$, while combining multiple nanocrystals in different directions.

OD are usually employed in cosmetic products. They can be produced using "topdown" and "bottom-up" methods. In "top-down" techniques, also called destructive techniques, nanosystems are produced starting from materials of higher dimensions, socalled bulk materials, which are decomposed into smaller components. High energy is required to overcome the internal binding forces $[15,16]$. "Bottom-up" techniques, or constructive techniques, produce nanosystems through the assembly of relatively simpler atomic or molecular compounds [16]. This approach allows for better control of the desired characteristics, such as morphology and size, but it is limited by low yields. On the other hand, "top-down" methods are easier to reproduce on a large scale, but can lead to stability problems for the loaded actives, given the high temperatures and pressures required [15]. According to their chemical composition, nanosystems used in cosmetic products fall within the following categories: (1) lipid nanosystems (nanoemulsions, vesicles, lipid nanoparticles); (2) polymeric nanoparticles; (3) inorganic nanoparticles; and (4) carbonbased nanoparticles [15,17-24] (Table 1). 


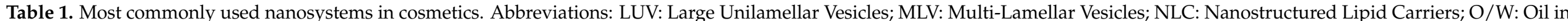
Water; SLN: solid lipid nanoparticles; SUV: Small Unilamellar Vesicles; W/O: Water in Oil.

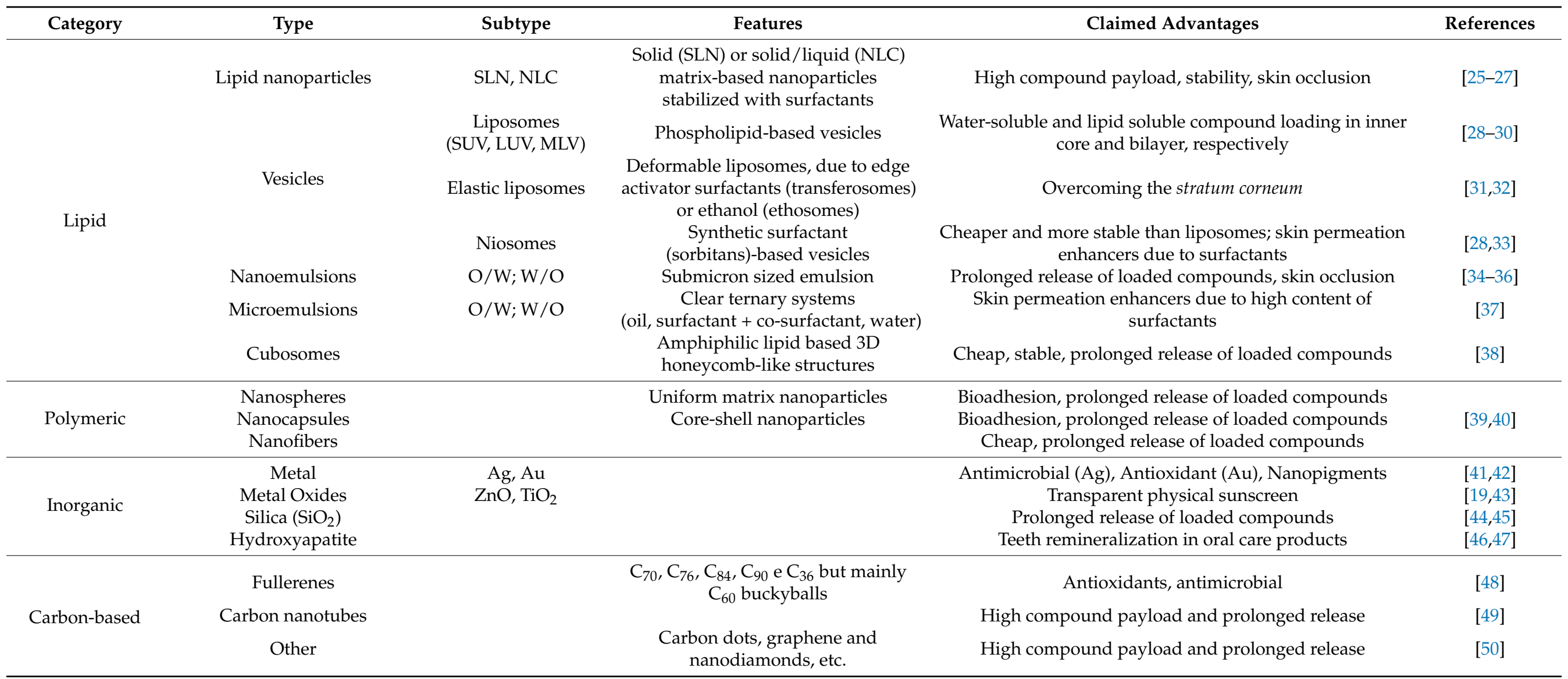


Despite the widespread use of nanosystems in cosmetic formulations, as well as the innovative properties of nanomaterials, relevant concerns regarding the safety of such nanomaterials as cosmetic ingredients are arising. Therefore, in order to determine whether a nanomaterial is safe for human health and the environment, a series of parameters should be evaluated [51,52]. To this aim, the suitable characterization of the nanomaterial should be performed. In the European Union (EU) this occurs according to the Scientific Committee on Consumer Safety (SCCS) "Guidance on the Safety Assessment of Nanomaterials in Cosmetics" [53]. The choice of key parameters to be measured and of the suitable characterization methods depends upon the composition, properties and foreseen use of the nanomaterial. This issue has been the subject of discussion in many international expert committees and working groups. In conclusion, the physico-chemical parameters that are considered relevant for the characterization of nanomaterials for safety assessment purposes have been reported in Table 2, together with the main analytical characterization techniques employed $[15,24,51-56]$.

Table 2. Most important characterization methods for nanomaterials. Abbreviations: AAS: Atomic Absorption Spectroscopy; AFM: Atomic Force Microscopy; BET: Brunauer Emmett and Teller; CLS: Centrifugal Liquid Sedimentation; DSC: Differential Scanning Calorimetry; DLS: Dynamic Light Scattering; FFF: Field Flow Fractionation; FTIR: Fourier Transformed InfraRed; GC/LC-MS: Gas Chromatography/Liquid Chromatography-Mass Spectroscopy; GE: Gel electrophoresis; HDC: Hydrodynamic Chromatography; HPLC: High Performance Liquid Chromatography; ICP-MS: Inductively Coupled Plasma-Mass Spectrometry; IR: Infra-Red; LDE: Laser Doppler Electrophoresis; MS: Mass Spectroscopy; MW: Molecular Weight; NM: nanomaterial; NMR: Nuclear Magnetic Resonance; RS: Raman Spectroscopy; SEM: Scanning Electronic Microscopy; SLS: Static Light Scattering; TEM: Transmission Electronic Microscopy; UV-Vis: Ultraviolet-Visible; XRD: X Ray Diffraction; XPS: X Ray Photoelectron Spectroscopy.

\begin{tabular}{|c|c|c|c|}
\hline Information Category & $\begin{array}{l}\text { Relevant Parameters for } \\
\text { NM Characterization }\end{array}$ & $\begin{array}{l}\text { Analytical } \\
\text { Technique }\end{array}$ & $\begin{array}{l}\text { Specific Information } \\
\text { Gathered }\end{array}$ \\
\hline \multirow{6}{*}{ Chemical identity } & \multirow{6}{*}{$\begin{array}{l}\text { formula/molecular structure } \\
\text { of the NM constituents }\end{array}$} & AAS & metal/inorganic content \\
\hline & & FTIR & functional groups: chemical structure \\
\hline & & ICP-MS & metal/inorganic content \\
\hline & & Mössbauer & metal/inorganic content \\
\hline & & MS & $\begin{array}{c}\text { molecular ion, fragmentation spectrum: MW, } \\
\text { chemical structure }\end{array}$ \\
\hline & & $\begin{array}{c}\text { NMR } \\
\left({ }^{1} \mathrm{H} \text { and }{ }^{13} \mathrm{C}\right)\end{array}$ & functional groups: chemical structure \\
\hline \multirow{10}{*}{ Chemical composition } & \multirow{10}{*}{$\begin{array}{c}\text { purity; } \\
\text { nature of impurities; } \\
\text { coatings/surface moieties; } \\
\text { doping material; } \\
\text { encapsulated materials; } \\
\text { processing chemicals; } \\
\text { dispersing agents; } \\
\text { other additives } \\
\text { (i.e., stabilizers) }\end{array}$} & AAS & $\begin{array}{l}\text { metal/inorganic impurities \& doping materials } \\
\text { calorimetric transitions: melting }\end{array}$ \\
\hline & & DSC & $\begin{array}{l}\text { temperature/enthalpy; } \\
\text { polymorphism }\end{array}$ \\
\hline & & FTIR & $\begin{array}{l}\text { functional groups: doping materials, processing } \\
\text { chemicals }\end{array}$ \\
\hline & & GC/LC-MS & $\begin{array}{c}\text { analytical separation \& identification: purity; nature } \\
\text { of impurities, encapsulated actives, processing } \\
\text { chemicals }\end{array}$ \\
\hline & & HPLC & $\begin{array}{c}\text { analytical separation: purity, encapsulated actives, } \\
\text { processing chemicals }\end{array}$ \\
\hline & & ICP-MS & metal/inorganic impurities \& doping materials \\
\hline & & Mössbauer & metal/inorganic impurities \& doping materials \\
\hline & & $\begin{array}{c}\text { NMR } \\
\left({ }^{1} \mathrm{H} \text { and }{ }^{13} \mathrm{C}\right)\end{array}$ & $\begin{array}{l}\text { funtional groups: doping materials, processing } \\
\text { chemicals }\end{array}$ \\
\hline & & SEM & elemental analysis \\
\hline & & UV-Vis & $\begin{array}{l}\text { functional groups, UV extintion coefficient: chemical } \\
\text { structure }\end{array}$ \\
\hline \multirow{3}{*}{ Crystallographic structure } & \multirow{3}{*}{$\begin{array}{l}\text { crystalline form: amorphous, } \\
\text { polycrystalline, crystalline; phase/volume fraction; } \\
\text { spatial distribution }\end{array}$} & DSC & $\begin{array}{c}\text { calorimetric transitions: liquid crystals; } \\
\text { polymorphism }\end{array}$ \\
\hline & & XRD & crystal structure \\
\hline & & TEM & 2D transmitted electronic image \\
\hline \multirow{6}{*}{ Particle size and size distribution } & \multirow{6}{*}{$\begin{array}{c}\text { distribution diagrams for agglomerates/aggregates: } \\
\text { number versus size; number weighted sum function } \\
\text {-cumulative numbers; } \\
\text { batch-to-batch variation }\end{array}$} & $\begin{array}{l}\text { AFM } \\
\text { CLS }\end{array}$ & $\begin{array}{c}\text { probe scan image } \\
\text { density/size separation }\end{array}$ \\
\hline & & DLS & $\begin{array}{l}\text { mean particle size and polydispersity, } \\
\text { size distribution }\end{array}$ \\
\hline & & FFF/HDC & size/MW based separation: size distribution, \\
\hline & & SEM & $\begin{array}{l}\text { presence of agglomeration or aggregation } \\
\text { 3D backscattered electronic image }\end{array}$ \\
\hline & & SLS & mean particle size \\
\hline & & TEM & 2D transmitted electronic image \\
\hline
\end{tabular}


Table 2. Cont.

\begin{tabular}{|c|c|c|c|}
\hline Information Category & $\begin{array}{l}\text { Relevant Parameters for } \\
\text { NM Characterization }\end{array}$ & $\begin{array}{l}\text { Analytical } \\
\text { Technique }\end{array}$ & $\begin{array}{c}\text { Specific Information } \\
\text { Gathered }\end{array}$ \\
\hline Morphology/Shape/Structure & $\begin{array}{c}\text { state/physical form: powder, solution, suspension; } \\
\text { shape: spherical, tube, rod; aggregation: primary } \\
\text { particulates/agglomerates; } \\
\text { spatial distribution: homogeneous mixture, } \\
\text { core-shell, surface coating }\end{array}$ & $\begin{array}{l}\text { AFM } \\
\text { SEM } \\
\text { TEM } \\
\text { XRD }\end{array}$ & $\begin{array}{c}\text { probe scan image } \\
\text { 3D backscattered electronic image } \\
\text { 2D transmitted electronic image } \\
\text { crystal structure }\end{array}$ \\
\hline Surface characteristics & $\begin{array}{c}\text { surface charge: Zeta potential; } \\
\text { morphology/topography; } \\
\text { interfacial tension; } \\
\text { reactive sites; } \\
\text { chemical/biochemical modifications/coatings; } \\
\text { surface contaminants }\end{array}$ & $\begin{array}{c}\text { FTIR } \\
\text { GE } \\
\text { LDE } \\
\text { NMR } \\
\left({ }^{1} \mathrm{H} \text { and }{ }^{13} \mathrm{C}\right) \\
\text { RS } \\
\text { XPS }\end{array}$ & $\begin{array}{c}\text { functional groups: reactive sites, coatings, surface } \\
\text { moieties } \\
\text { MW based separation: coatings/functionalization } \\
\text { with proteins } \\
\text { Zeta potential } \\
\text { functional groups: reactive sites, coatings or surface } \\
\text { moieties } \\
\text { surface binding, coatings, surface moieties of } \\
\text { Carbon based materials } \\
\text { surface elemental analysis }\end{array}$ \\
\hline Surface area & $\begin{array}{l}\text { specific surface area. } \\
\text { volume-specific surface area }\end{array}$ & BET & surface area calculation by gas absorption \\
\hline Concentration & $\begin{array}{l}\text { particle mass / } \\
\text { particle number per volume }\end{array}$ & $\begin{array}{l}\text { AAS } \\
\text { GC/LC-MS } \\
\text { HPLC } \\
\text { ICP-MS } \\
\text { UV-Vis }\end{array}$ & $\begin{array}{l}\text { metal/inorganic dose quantification } \\
\text { analytical separation: dose quantification } \\
\text { analytical separation: dose quantification } \\
\text { metal/inorganic dose quantification } \\
\text { dose quantification }\end{array}$ \\
\hline Stability & $\begin{array}{l}\text { stability/dissociation constants } \\
\text { in relevant } \\
\text { formulation/media }\end{array}$ & $\begin{array}{l}\text { DLS } \\
\text { DSC } \\
\text { FTIR } \\
\text { GC/LC-MS } \\
\text { HPLC } \\
\text { MS } \\
\text { NMR } \\
\left({ }^{1} \mathrm{H} \text { and }{ }^{13} \mathrm{C}\right) \\
\text { SLS }\end{array}$ & $\begin{array}{c}\text { mean particle size and polydispersity; } \\
\text { size distribution } \\
\text { calorimetric transitions: polymorphism } \\
\text { functional groups: chemical structure } \\
\text { analytical separation \& identification: dose } \\
\text { quantification } \\
\text { analytical separation: dose quantification } \\
\text { molecular ion, fragmentation spectrum: chemical } \\
\text { structure } \\
\text { functional groups: chemical structure } \\
\text { mean particle size }\end{array}$ \\
\hline
\end{tabular}

Both nanomaterial physical form and surface chemical reactivity should be considered: size, shape, morphology influence, deposit site, clearance and biological responses, while the interactions with organisms and the environment depends mainly upon the surface area and chemistry [51]. Indeed, risks to health and the environment may not only arise from the chemical composition of nanomaterials, but also from their size and surface features (e.g., coatings), which, in turn, can modulate absorption, biokinetics and toxic effects [53].

In this context, the determination of the chemical identity and composition of the nanomaterial, in terms of purity, presence of impurities, coatings, doping and encapsulated materials, processing chemicals, dispersing agents and additives, can be achieved using several spectroscopic techniques, according to the chemical nature of the material, which can be both organic (Mass Spectroscopy, Fourier Transformed Infra-RedFTIR, Nuclear Magnetic Resonance-NMR) and inorganic (Atomic Absorption Spectroscopy, Inductively Coupled Plasma-Mass Spectrometry, Mössbauer). Chromatographic techniques (High Performance Liquid Chromatography; Gas Chromatography) are also employed, with the aim of achieving the analytical separation of chemical moieties. Differential Scanning Calorimetry, together with X-Ray Diffraction, provides information about the crystalline state and potential polymorphisms. Particle size and morphology/structure determination are of primary importance: methods that are based upon light scattering (Dynamic \& Static Light Scattering) and density/size separation (Field Flow Fractionation, Hydrodynamic Chromatography, Centrifugal Liquid Sedimentation) can be used to measure mean particle size and size distribution. The latter is very important in the case of agglomerates and aggregates, which are likely to have different chemical and biological properties than the isolated particles. However, the use of more than one characterization method is recommended for particle size, and can include electron microscopy-based imaging (Transmission Electron Microscopy \& Scanning Electronic Microscopy), which are also of prior relevancy for the determination of shape (spherical, tube, rod), aspect ratio (for fiber/tube-like materials) and spatial distribution (e.g., homogeneous mixture, core-shell, 
surface coating). Surfaces should be characterized in terms of specific area (Brunauer Emmett and Teller) and characteristics. In particular, surface charge (Zeta potential) can be measured using light scattering (Laser Doppler Electrophoresis), reactive sites and surface functionalization/modification (i.e., coatings) can be detected using spectroscopic methods (FTIR, NMR, Raman Spectroscopy, X Ray Photoelectron Spectroscopy), and Gel Electrophoresis can be used in the case of protein ligands [15,24,51,52,54-56].

Moreover, further risks to health and the environment are posed if a nanomaterial loses its nanostructure. Therefore, the determination of nanomaterial stability, using the abovementioned methods, is of primary importance. Indeed, since reactions that occur during handling or storage can modify interactions with biological systems, the characterization of nanomaterials in a cosmetic product should takes place in three phases: (1) at the manufacturing of the nanomaterial (pure state); (2) after the addition to the finished cosmetic (consumer exposure); (3) under usage conditions (toxicological investigation) [53].

\section{Cosmetic Functions of Nanosystems}

In the EU, a cosmetic product is defined as "any substance or preparation intended to be placed in contact with the various external parts of the human body (epidermis, hair system, nails, lips and external genital organs), or with the teeth and the mucous membranes of the oral cavity, with a view, exclusively or mainly, to cleaning them, perfuming them, changing their appearance and/or correcting body odours and/or protecting them or keeping them in good condition" [57]. A cosmetic product is therefore defined by its site of application (skin and annexes) and its primary functions, and excludes any therapeutic effects. Since intact skin is the primary application site for cosmetic products, many nanosystems claim to benefit the different layers of the epidermis (nourishment, hydration), or to penetrate further into the dermis to repair damaged cells and matrices (e.g., collagen, elastin), and these products include anti-aging ones $[18,21,58]$. However, according to the above definition, the skin penetration of cosmetic active ingredients, although desirable, must be strictly controlled to the viable epidermis and dermis, without reaching systemic circulation, as transcutaneous delivery exceeds the specific cosmetic functions [18].

Several different cosmetic functions can be attributed to nanosystems (Table 1), and these can be grossly divided into: (1) improvement of intrinsic properties of cosmetic ingredients and finished cosmetic products; (2) increased skin permeation (with the abovementioned limitations).

The former category includes: sustained release, increased physico-chemical stability, reduced irritability, improved textural quality and improved dispersion/spreading properties for the active cosmetic ingredients. Sustained release can be achieved via various mechanisms. Indeed, nanosystems can be divided into two major categories, according to their release properties: the first, which 'disintegrates' upon application onto the skin, includes vesicles and lipid nanosystems; the second, which remains 'insoluble' and 'persistent' throughout its usage, includes polymeric, inorganic and carbon based nanoparticles [21]. With regards to improvements in physico-chemical stability, nanosystems can be used for the protection of volatile compounds (such as perfumes), and sensitive compounds (such as hydroquinone) [59-61]. On the other hand, they can secure diminished direct skin contact with irritant molecules, such as dihydroxyacetone [59]. Finally, reducing the particle size to the nano range improves spreadability and provides transparency to titanium dioxide and zinc oxide, which are commonly used as physical UV filters [62].

The skin penetration of intact nanosystems, however, is a highly debated topic [63,64]. The suitable interpretation of literature data can come from a careful consideration of permeation pathways (transcellular vs. transappendageal) (Figure 1), size impact and the deepness of permeation [65]. The transappendageal route has no size limit (within the nanometer range), but is restricted to relatively small areas of the human body (less than $0.1 \%$ of the total surface), while the transcellular/paracellular ways are highly limited by the compact structure of the stratum corneum, which can be overcome only by lipophilic and low MW (<200 Da) molecules, owing to partition mechanisms [66]. Recent insights 
into skin structure have revealed that corneocytes in the stratum corneum are organized into clusters and surrounded by so-called "canyons". These structures are filled with a non-polar, poorly hydrated material. With a size of nearly 20-30 nm, larger than the inter-corneocytes spaces $(0.4 \mathrm{~nm})$, they may allow the so-called "inter-cluster" pathway to be followed. However, it has been speculated that this permeation pathway may drive mainly in a lateral direction, while these "canyons" should act as a reservoir of hydrophobic compounds, due to their chemical composition [67-71].

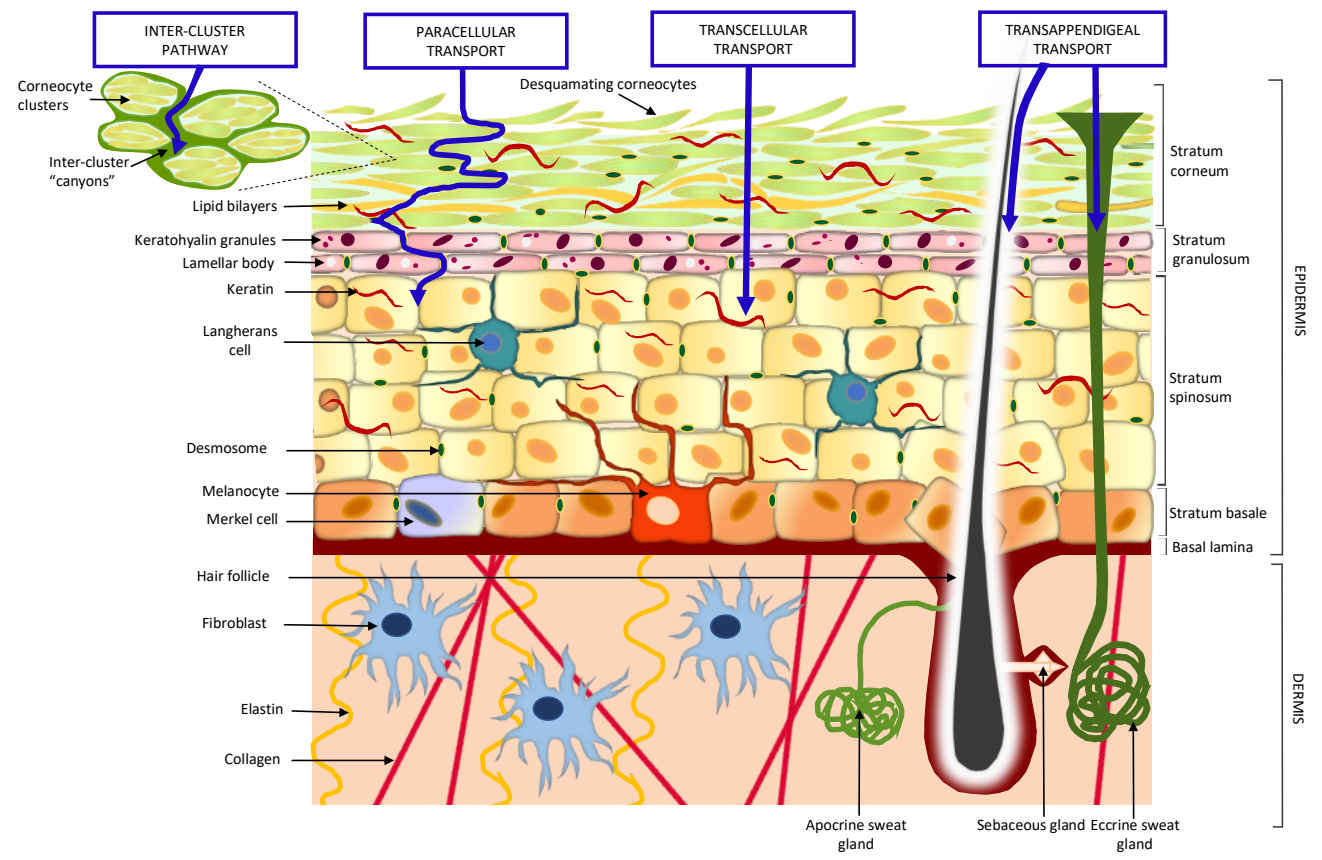

Figure 1. Absorption pathways through the skin.

This, in turn, reflects in the poor permeation of nanosystems through intact skin. An interesting article has reviewed the existing experimental work on the skin permeation of nanosystems, in terms of penetration path (transappendageal vs. transcellular/paracellular), depth and the influence of size [65]. Provided that diffusion via hair follicles and/or sweat glands contributes to skin permeation to a lesser extent, it was noticed that no nanosystem reached the dermis via the transcellular/paracellular route. Only a few nanosystems of those smaller than $10 \mathrm{~nm}$ showed some skin penetration, but this was limited to the viable epidermis, without reaching the dermis. Larger nanosystems were confined to the stratum corneum [65] (Figure 2).

A well-known exception to this rule can be found in deformable liposomes (i.e., transferosomes and ethosomes), in which surfactants and/or ethanol act as edge activators, allowing the vesicles to deform throughout the stratum corneum matrix. However, it is difficult to discriminate between their main claimed property and other simultaneous permeation mechanisms (Figure 3) [31,32]. IDEA AG holds the first international patents (1991 and later) that cover preparations based on such amphipathic aggregates, including those containing alcohols, which are mainly used for drug-delivery purposes [68]. Nonetheless, they can also be employed for cosmetic purposes [72]. Some marketed products are also based on ethosomes [73-76]. 


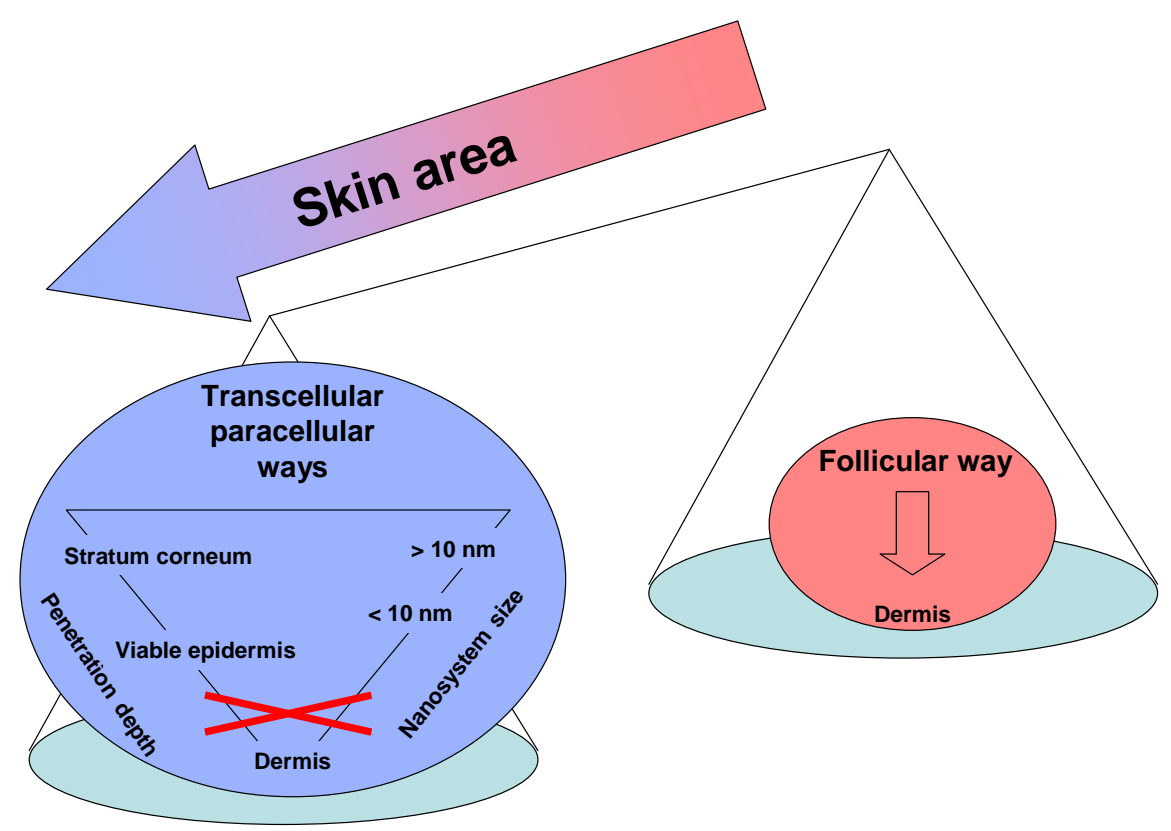

Figure 2. Permeation pathways of nanosystems through the skin.

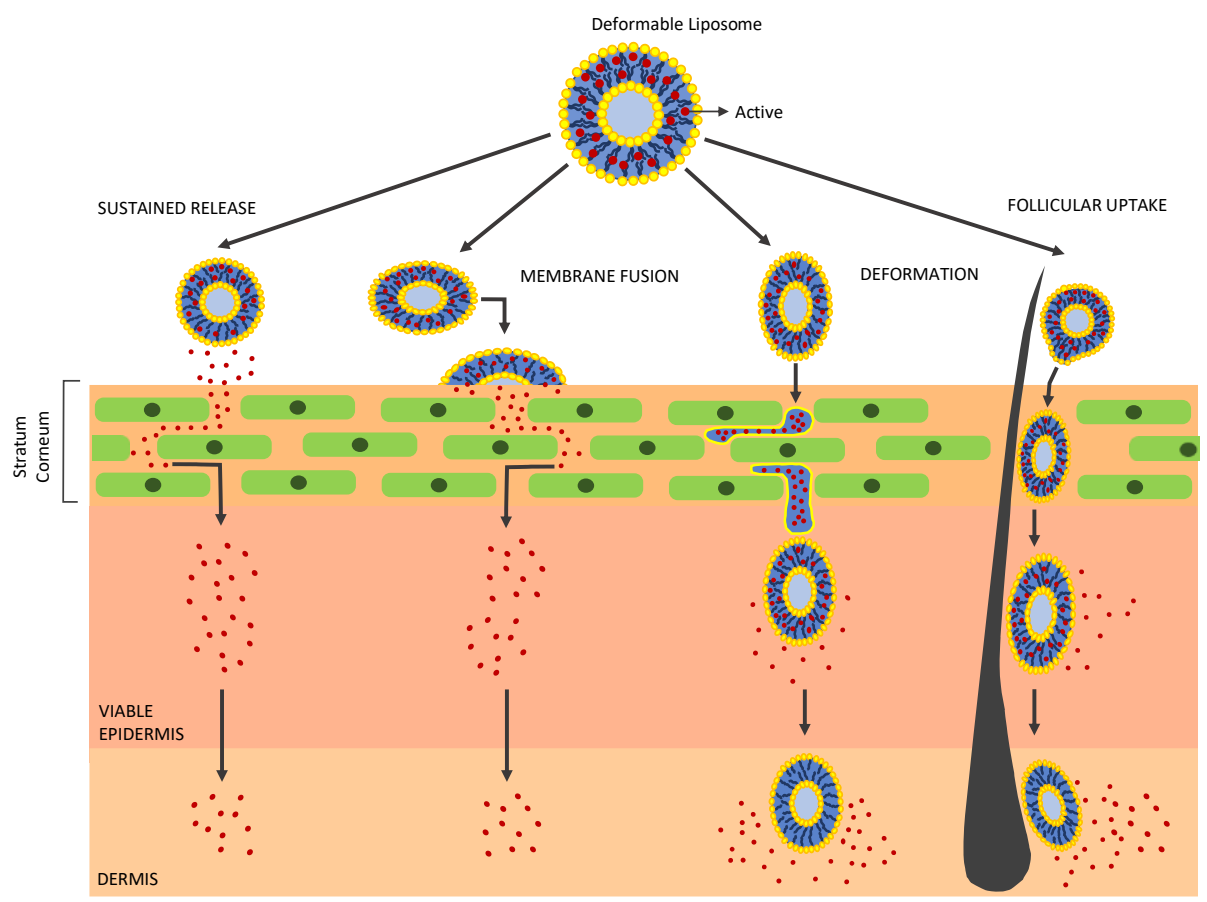

Figure 3. Mechanisms underlying the skin permeation of deformable liposomes.

However, nanosystems can act as permeation enhancers for loaded active ingredients, via multiple indirect mechanisms, although intact nanosystems are unable to permeate. This is typical of lipid nanoparticles, which act as permeation enhancers via skin hydration and increased permeability, due to the occlusion effect of the lipids [25-27]. Moreover, surfactants that are used to formulate and/or stabilize such nanosystems play a key role in altering the compact structure of the stratum corneum, and therefore facilitate the skin permeation of compounds; this mechanism is particularly relevant for microemulsions, which are stabilized by highly concentrated surfactants [37]. 


\section{Market Overview}

The nano-market in cosmetic products began at the end of the eighties. The first liposome-containing marketed cosmetic product was the anti-age "Capture", launched by Christian Dior in 1986 [77]. This was followed, in 1998, by "Plentitude Revitalift" (L'Oréal), an anti-aging cream containing polymeric nanocapsules for the delivery of active ingredients (e.g., retinol) [21]. This company allocated approximately 600 million \$ (within its 17 billion \$ profit) to "nano" patents [22,29], ranking them sixth among nanotechnology patent holders in the United States of America (USA) [22]. Pureology began employing nanoemulsions in 2000, when the company's founder created a specific cosmetic line for hair dyes. In 2003, Caudalie, based in Paris, launched "Vinosun", a sunscreen and anti-aging product containing nanometric UV filters and antioxidants [21]. In 2006, the cosmetics giant Estèe Lauder also began employing nanotechnology in its cosmetic products [22], followed by Procter \& Gamble, Johnson \& Johnson, Avon, Colorscience, and Doctor's Dermatologic Formula [21,22]. Today, almost 40 years later, the use of nanotechnology in marketed cosmetic products worldwide is so widespread [18-22,78,79], that current attempts to categorize them (Table 3) fast become out of date, while updated distributions can be obtained from comprehensive market reports, performed by advanced technology consultancies [80]. 


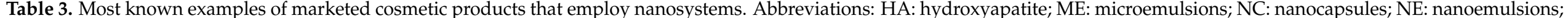
NLC: nanoxtructured lipid carriers; NP: nanoparticles; NS: nanospheres; Nsom: nanosomes; SLN: solid lipid nanoparticles.

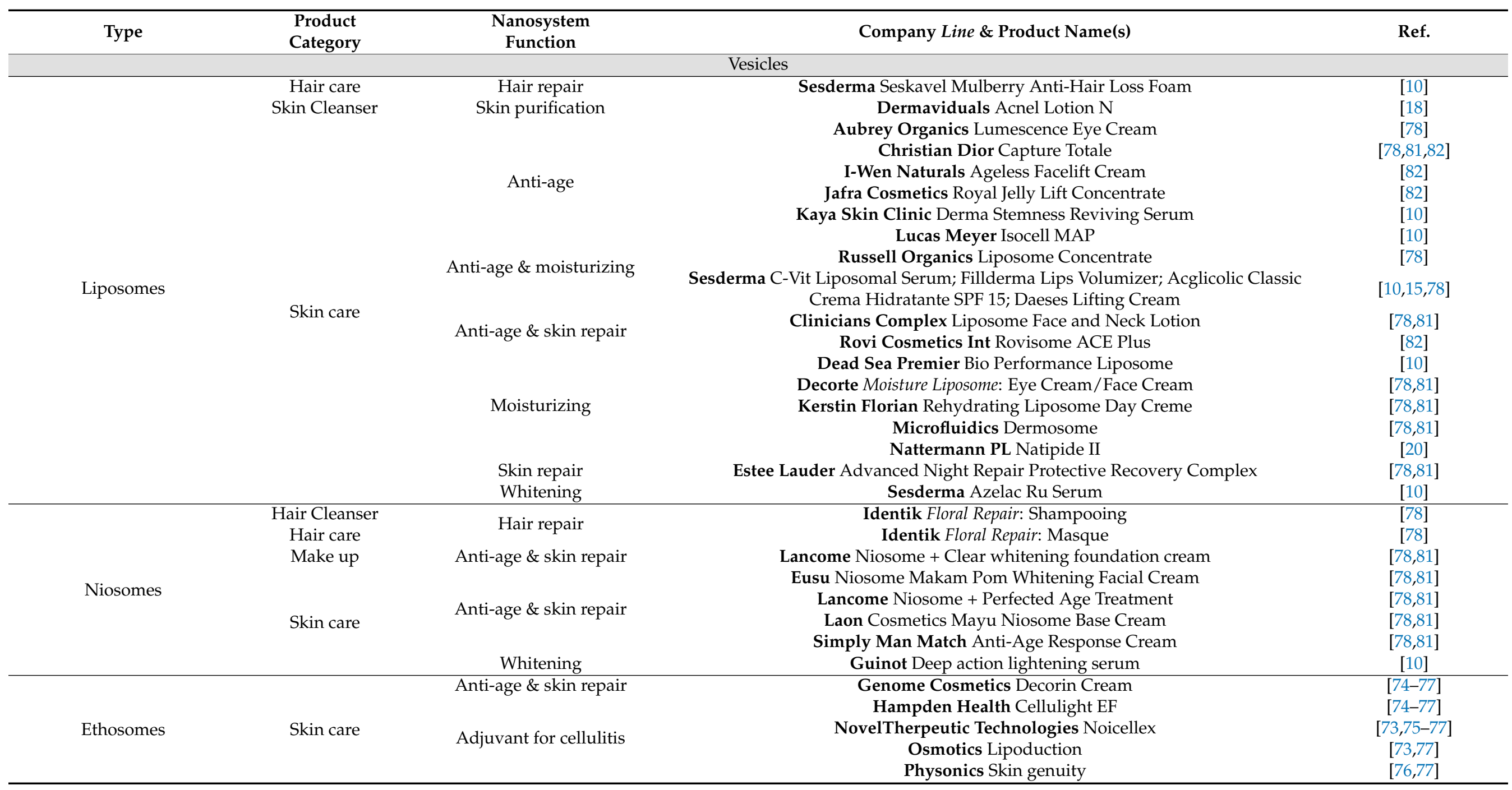


Table 3. Cont.

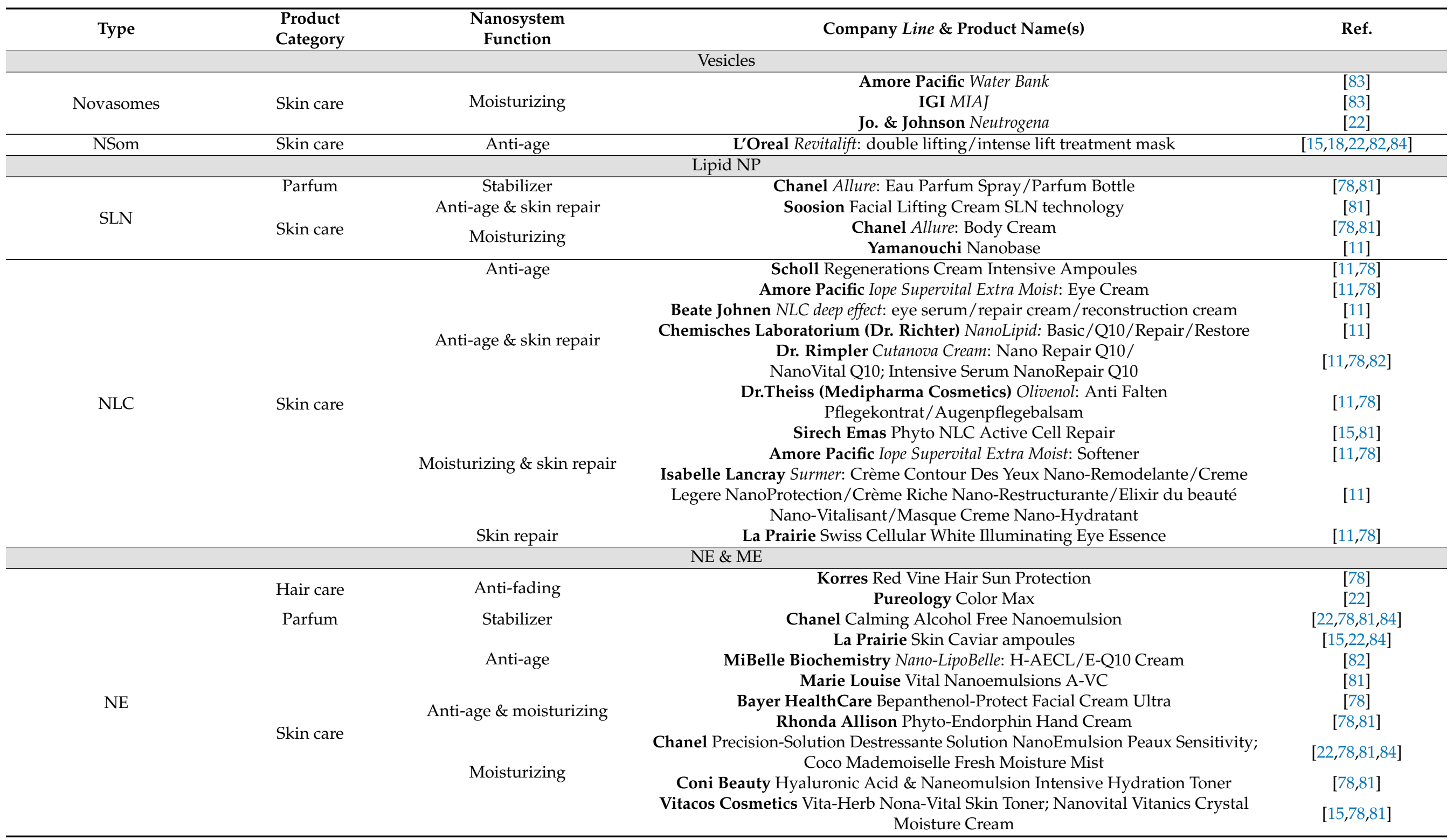


Table 3. Cont.

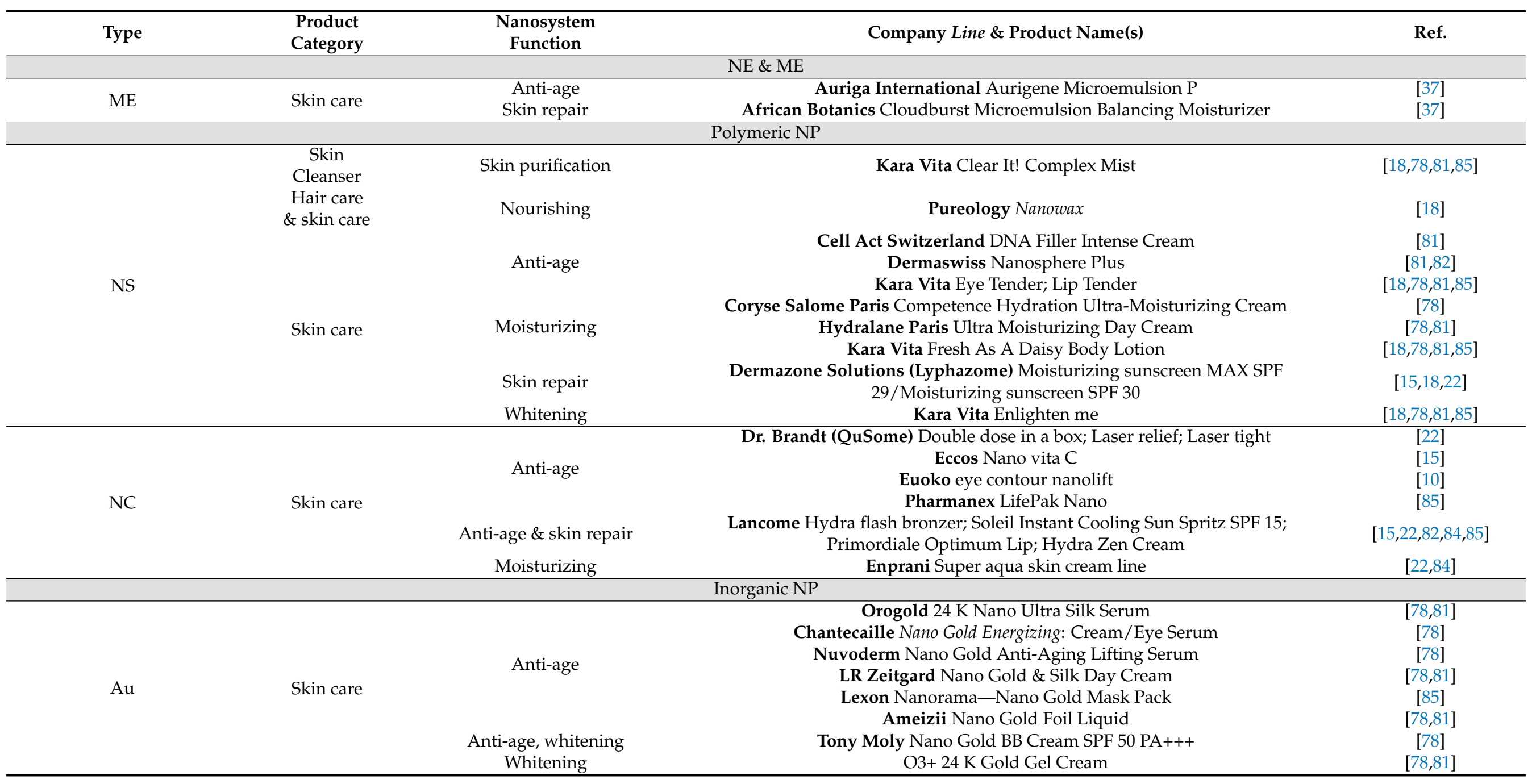


Table 3. Cont.

\begin{tabular}{|c|c|c|c|c|}
\hline Type & $\begin{array}{l}\text { Product } \\
\text { Category }\end{array}$ & $\begin{array}{l}\text { Nanosystem } \\
\text { Function }\end{array}$ & Company Line \& Product Name(s) & Ref. \\
\hline \multicolumn{5}{|c|}{ Inorganic NP } \\
\hline \multirow{3}{*}{$\mathrm{Ag}$} & Skin & \multirow{3}{*}{ Skin purification } & NanoCyclic Cleanser Silver & [85] \\
\hline & Cleanser & & Natural Korea Cosil: Nano Beauty Soap & {$[85]$} \\
\hline & Skin care & & Natural Korea Cosil: Whitening Mask & [85] \\
\hline $\mathrm{Au}+\mathrm{Ag}$ & Skin care & Anti-age \& skin purification & Joyona International Marketing Nano Gold 24 Hour Cream & {$[18,21,79]$} \\
\hline \multirow{4}{*}{$\mathrm{ZnO}$} & $\begin{array}{l}\text { Skin } \\
\text { Cleanser }\end{array}$ & Adsorbent & Nano-Infinity Nanotech Nano-in Deep Cleaning & {$[18,21]$} \\
\hline & & \multirow{3}{*}{ Sunscreen } & Antaria Zinclear & [84] \\
\hline & Skin care & & Dermatone Moisfurizing lips ‘n face protection crème & [22] \\
\hline & & & Procter \& Gamble Olay complete UV protective moisture lotion & [22] \\
\hline \multirow{2}{*}{$\mathrm{TiO}_{2}$} & & \multirow{2}{*}{ Sunscreen } & Boots (Optisol) Soltan facial sun defence cream & [22] \\
\hline & Skin care & & Christian Dior DiorSnow Pure UV Base SPF 50 & {$[82,85]$} \\
\hline \multirow{2}{*}{$\mathrm{ZnO}+\mathrm{TiO}_{2}$} & Make up & \multirow[b]{2}{*}{ Sunscreen } & Colore Science Sunforgettable: corrector colores SPF 20/SPF 30 brush range & {$[22,84]$} \\
\hline & Skin care & & Colore Science Wild to mild skin bronzer & {$[22,84]$} \\
\hline \multirow{3}{*}{$\mathrm{SiO}_{2}$} & \multirow{3}{*}{ Skin care } & \multirow{3}{*}{ Antiage \& skin care } & Global Med Tech. Leorex hypoallergenic wrinkle nano remover line & {$[22,84]$} \\
\hline & & & Lancome Renergie: lift makeup/microlift eye & {$[22,82,84]$} \\
\hline & & & Shiseido Elixir skin range; Pureness matifying compact & {$[22]$} \\
\hline Mica & Make up & Colorant & Colore Science Dual Finished Pressed Compacts & [18] \\
\hline \multirow[t]{2}{*}{ HA } & Toothpaste & Abrasive & Apagard Apagard Premio toothpaste & [86] \\
\hline & & \multicolumn{2}{|r|}{ Carbon based } & \\
\hline \multirow{4}{*}{ Fullerenes } & \multirow{4}{*}{ Skin care } & \multirow{3}{*}{ Anti-age \& skin repair } & $\begin{array}{c}\text { Dr. Brandt New lineless cream } \\
\text { Sircuit Cosmeceuticals White out/Daily under eye care }\end{array}$ & $\begin{array}{c}{[22]} \\
{[21,22,79,82]}\end{array}$ \\
\hline & & & Bellapelle Skin Studio Defy: Age management exfoliator/EGF complex & {$[18,22]$} \\
\hline & & & MyChelle Dermaceuticals Revitalizing night cream & [22] \\
\hline & & Skin repair & Zelens Fullerene $C_{60}$ : day cream/night cream & {$[22,82]$} \\
\hline
\end{tabular}


On the other hand, additional information on marketed cosmetic products that contain nanosystems can be gathered from two freely available resources [80]. The first is the "Global Nanotechnology Database", launched by StatNano in 2014 and regularly updated [87]. It includes three databases that cover international nanotechnology standards, global nanotechnology events and different countries' policy documents. The second is the "Nanotechnology Consumer Products Inventory" (CPI) [88], a web resource created in 2005 by the "Project on Emerging Nanotechnologies", together with the "Woodrow Wilson International Center for Scholars", with the aim of gathering information on marketed "nano" products. To be included in the CPI, nanotechnology products must meet three criteria: (1) be easily purchased by consumers; (2) claim nanomaterial content, either by the manufacturer or by another source; (3) appear to be suitable in the opinion of the CPI curatorial staff [89]. However, this inventory is solely based on web information, and thus excludes any product that is not present on the internet. Furthermore, the CPI is updated by crowd-sourcing, thus allowing any user to suggest changes. This is a significant limitation as the CPI clearly specifies that neither the verification of the claims made by the manufacturers nor independent product tests are carried out [90]. According to these databases, cosmetic products represent $12 \%$ of the total nanomaterial-based products, while USA, Brazil, UK, Germany, France, South Korea, Russia, Poland, Switzerland and Malaysia are the top ten countries in promoting nanotechnology in the cosmetics industry.

Nanosystems are employed in a wide range of marketed cosmetic categories: skincare and hair care, cleansers, make up and toothpastes [78,91]. Vesicles are mainly employed to improve skin retention and the release of anti-age, moisturizing, skin repair and whitening ingredients [81,82]. Besides liposomes, more recent nanosystems have also been marketed, and these include niosomes, the afore-mentioned ethosomes and novasomes, which are innovative multi-lamellar systems composed of synthetic surfactants [83]. Solid lipid nanoparticles (SLN), nanostructured lipid carriers (NLC) and nanoemulsions (NE) are made up of nourishing and moisturizing triglycerides and wax esters. Unlike SLN, which are exclusively composed of solid lipids, NLC contain mixtures of solid and liquid lipids, and provide an improved payload of the active ingredients [11]. From a technological point of view, the low energy Phase Inversion Temperature (PIT) technology, introduced by Vitacos Cosmetics to formulate an NE, is a relevant research innovation that is retained by marketed products. PIT technology couples small droplet sizes $(<50 \mathrm{~nm})$ and high lipid content $(>20 \%)$, which, in turn, improves the retention of the loaded cosmetic ingredients in the deep skin layers $[15,78]$. Nonetheless, the comedogenic effect of the most commonly used lipids is a relevant hurdle. For instance, African Botanics was able to overcome this with an anti-age microemulsion based on a high concentration of natural and anticomedogenic lipids, which are also suitable for acneic skins [37]. Polymeric nanoparticles are also widely used in marketed products, with the aim of improving the delivery of the loaded anti-age, nourishing and moisturizing active ingredients. Different proprietary nanotechnologies and/or "nano-brands" are retained by cosmetic companies, such as QuSome (Dr Brandt), and Liphazome (Dermazone Solutions) [22,81,84,85].

Moving now to inorganic nanoparticles, transparent nanopigments $\mathrm{ZnO}$ and $\mathrm{TiO}_{2}$, antimicrobial Ag, antioxidant $\mathrm{Au}$ and silica are the most reported $[22,81,82,84,85]$. Of particular interest from a technological viewpoint is Optisol, an innovative form of $\mathrm{TiO}_{2}$ that has been patented by Boots, and contains a small amount of manganese, which improves UVA protection and acts as a radical scavenger in sunscreen products [18,22]. Finally, recent market interest is growing towards fullerenes, which are carbon-based nanoparticles $\left(\mathrm{C}_{60}\right)$, known for their strong antioxidant and antimicrobial activities, that are mainly used in anti-age and skin-repair products [21,22,79].

It should be noticed that certain nanosystems can only be used in some formulations, rather than all of them, depending on the cosmetic category and/or intended use. An additional reason for this is that, in some cases, there may be incompatibility between the nanosystem and the other cosmetic ingredients [92,93]; some metal oxides, such as zinc oxide, are very difficult to formulate at acidic $\mathrm{pH}$ [94]. Moreover, some nanosystems can 
alter the mechanisms of action of surfactants/emulsifiers and gelling agents, decreasing the stability of the final cosmetic products. Nano titanium dioxide is also photo-reactive with a resulting increase in reactive oxygen species (ROS), which are implicated in cellular damage. This issue has been solved by coating nanoparticles with alumina or silica to quench the production of ROS. This, in turn, also improves the dispersion of nanoparticles and their compatibility with other ingredients within sunscreen formulations [95]. Therefore, the engineering of innovative nano-ingredients that are suitable for use in different formulations is an emerging topic, and there are several examples of nanosystems that are marketed as cosmetic ingredients by chemical companies in order to be included in various finished products by cosmetics manufacturers (Table 4).

Table 4. Most known examples of nanosystems marketed as cosmetic ingredients. Abbreviations: DHA: dihydroxyacetone;

$\mathrm{O} / \mathrm{W}$ : oil in water.

\begin{tabular}{|c|c|c|c|c|}
\hline Company & Nanosystem & Product(s) Name & Function & Ref. \\
\hline \multicolumn{5}{|c|}{ Vesicles } \\
\hline Applied genetics & Enzyme loaded & Ultrasomes; Photosome & Suncare products, skin repair & {$[73,96]$} \\
\hline BASF & DHA loaded & Elespher & DHA protection \& delivery & [96] \\
\hline BASF & & Catezome & Improved skin delivery & [96] \\
\hline \multicolumn{5}{|c|}{ Nanoemulsions } \\
\hline Sinerga & $\mathrm{O} / \mathrm{W}$ & Nanocream & $\begin{array}{l}\text { Sprayable, hyperfluid } \\
\text { emulsions; wet wipes }\end{array}$ & [78] \\
\hline \multicolumn{5}{|c|}{ Microemulsions } \\
\hline Abitec & Oily & $\begin{array}{l}\text { Caprol Microexpress } \\
\text { blends }\end{array}$ & $\begin{array}{l}\text { Sunscreens \& anti-age } \\
\text { actives delivery }\end{array}$ & [37] \\
\hline Dow Corning & Silicon & Dowsil & Hair care: conditioners, gels & [37] \\
\hline \multicolumn{5}{|c|}{ Nanoparticles } \\
\hline Advanced Nanotechnology & $\mathrm{Al}_{2} \mathrm{O}_{3}$ & $\begin{array}{l}\text { Alusion Aluminum } \\
\text { Powders }\end{array}$ & Adsorbent \& anti-caking & [18] \\
\hline Advancec Polymers Systems & Polymer & Microsponge & Improved skin delivery & {$[59,96]$} \\
\hline BASF & Nylon/silica & Elesponge & Emollient & [96] \\
\hline Degussa & $\mathrm{TiO}_{2}$ & Tego Sun TS Plus & Sunscreen & [82] \\
\hline Micronisers Pty & $\mathrm{ZnO}$ & NanoSun & Sunscreen, adsorbent & [82] \\
\hline
\end{tabular}

\section{Regulatory Landscape}

Currently, there is still a lack of an unambiguous definition-globally-that identifies nanomaterials as cosmetic ingredients. Therefore, each country follows its own definition and its own legislation [97]. As the EU and USA are the two largest markets for cosmetic products, a scheme of their regulatory frameworks is shown in Table 5. 


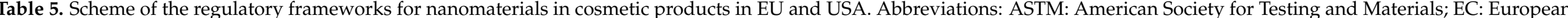

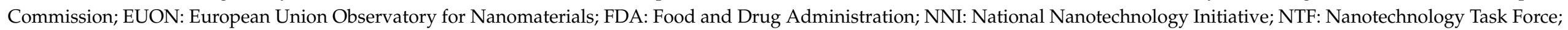
PCPC: Personal Care Products Council; REACH: Registration, Evaluation, Authorization and Restriction of Chemicals; SCCS: Scientific Committee on Consumer Safety.

Regulating authorities/organizations

Relevant documents released

$$
\begin{gathered}
\text { EC Regulation 1223/2009 [57] } \\
\text { EC Recommendation 696/2011 [99 }
\end{gathered}
$$$$
\text { SCCS Notes of Guidance 11th revision [101] }
$$

Guidance on the Safety Assessment of Nanomaterials in Cosmetics (SCCS) [53]

$$
\text { REACH updated Regulation 1907/2006 (2018) [103] }
$$

EC Regulation 1223/2009: "an insoluble or biopersistent and intentionally manufactured material, having one or more external dimensions, or an internal structure, on the scale from 1 to $100 \mathrm{~nm}^{\prime \prime}$

Nanomaterial definition

EC Recommendation 696/2011: "a natural, incidental or manufactured material containing particles, in an unbound state or as an aggregate or as an agglomerate and where, for 50\% or more of the particles in the number size distribution, one or more external dimensions is in the size range 1-100 $\mathrm{nm}$. In specific cases and where warranted by concerns for the environment, health, safety or competitiveness the number size distribution threshold of $50 \%$ may be replaced by a threshold between 1 and 50\%. By derogation from the above, fullerenes, graphene flakes and single-wall carbon nanotubes with one or more external dimensions below $1 \mathrm{~nm}$ should be considered as nanomaterials"
FDA; NTF, NNI, PCPC

Federal Food, Drug, and Cosmetic Act (FDA) [98] "Considering whether an FDA-Regulated Product Involves the Application of Nanotechnology" (FDA) [100] "Guidance for Industry-Safety of Nanomaterials in Cosmetic Products" (FDA) [102]

No approved definition by FDA; only two points from "Considering whether an FDA-Regulated Product Involves the Application of Nanotechnology" (2014) should be used to identify nanomaterials:

(1) if "a material or final product is designed to have at least one external dimension or internal or surface structure, in the external dimens material or final product is designed to exhibit p material or final product is designed to exhibit properties or phenomena, including physical or chemical properties or biological effects, which are attributable to its size, even if thes dimensions are outside the nanoscale range, down to one micrometer $(1000 \mathrm{~nm}) "$.

ASTM: "any technology that measures, manipulates or incorporates materials and/or resources from 1 to $100 \mathrm{~nm}^{\prime \prime}$ NNI: "nanotechnology is the development, understanding and control of materials at the nanoscale, ranging from 1 to $100 \mathrm{~nm}$ 


\subsection{EU}

\subsubsection{Definition of Nanomaterial and Regulating Authorities}

European Commission (EC) Regulation 1223/2009 provides a definition of nanomaterial for the cosmetic products, as "an insoluble or biopersistent and intentionally manufactured material, having one or more external dimensions, or an internal structure, on the scale from 1 to $100 \mathrm{~nm}$ " [57]. EC Recommendation 2011/696 updated this definition, in order to ensure compliance between different areas in which nanomaterials are used [99]. Accordingly, a nanomaterial is "a natural, incidental or manufactured material containing particles, in an unbound state or as an aggregate or as an agglomerate and where, for 50\% or more of the particles in the number size distribution, one or more external dimensions is in the size range 1-100 $\mathrm{nm}$. In specific cases and where warranted by concerns for the environment, health, safety or competitiveness the number size distribution threshold of $50 \%$ may be replaced by a threshold between 1 and $50 \%$. By derogation from the above, fullerenes, graphene flakes and single wall carbon nanotubes with one or more external dimensions below $1 \mathrm{~nm}$ should be considered as nanomaterials" [99].

Regulation 1223/2009, released by the EC in 2009, governs cosmetic products in the EU. Moreover, the SCCS provides guidance for industries and public authorities to ensure compliance with Regulation 1223/2009, with particular concern to the safety assessment of ingredients that are intended for use in cosmetic products [6]. If the EC raises doubts about the safety of a nanomaterial, it can request an opinion from the SCCS, which formulates its evaluation within six months of the request. If the SCCS finds that there is a lack of necessary data, the EC asks the person responsible to provide such data within a reasonable period, which is explicitly indicated and cannot be extended. The opinion of the SCCS is then made publicly available [57].

\subsubsection{EC Released Documents}

EC Regulation 1223/2009 provides specific rules for the labeling of cosmetic products that contain nanomaterials: each nanomaterial must be clearly indicated in the list of ingredients, placing the wording "nano" (in brackets) as a suffix to the name of the material. Furthermore, in the EU, all marketed cosmetics must name a responsible person (natural or legal), that has the task of supervising its conformity. Each cosmetic, before being marketed, must be electronically communicated to the EC through the Cosmetic Products Notification Portal (CPNP) by the responsible person, for market surveillance purposes. Additionally, the responsible person must communicate the existence of cosmetic products that contain new nanomaterials (that have not yet undergone full risk assessment by the SCCS) to the EC, in electronic format, six months before the products are marketed. Information provided should include nanomaterial identification, description (physicochemical characterization), estimated amount marketed per year, toxicological profile, safety data (related to the cosmetic product) and exposure conditions [57].

\subsubsection{SCCS Released Documents}

The SCCS, in 2021, issued the 11th revision of the "SCCS Notes of Guidance for the testing of cosmetic ingredients and their safety evaluation" [101], stating that the safety assessment of cosmetic products is based on the safety of the ingredients. This is established via risk assessment that is based on the level of exposure, which takes place on the basis of the toxicological data of the ingredients. To this aim, given the ban on animal testing for cosmetic ingredients in the EU [57], it is possible to consider the results reported in other relevant areas, but the use of this data must be duly supported and justified [101]. According to SCCS/1628/21, the safety evaluation of cosmetic products is based on the principles and practices of risk assessment that are usually applied for chemicals in the EU. Specifically, it is divided into four parts: (1) risk identification; (2) dose-response evaluation; (3) exposure assessment; (4) risk characterization [101]. Within these guidelines, reference is also made specifically to nanomaterials. For each cosmetic ingredient that meets the 
nanomaterial criteria, safety data is required from tests carried out, taking into account the properties of the nanoforms.

Moreover, the SCCS, in 2019, published the document "Guidance on the Safety Assessment of Nanomaterials in Cosmetics" [53]. This Guide represents the revision of the 2012 Nanomaterial Safety Assessment document [104]. It was intended to take into account new developments in nanomaterial safety, and to facilitate applicants and risk assessors in the preparation of nanomaterial safety assessment dossiers [53]. It is mainly focused on risk identification (through physico-chemical characterization) and exposure assessment, as starting points for the safety assessment of nanomaterials. Recently, SCCS/1611/19 was updated in the "Scientific advice on the safety of nanomaterials in cosmetics" [105]. This document aims to identify those specific physico-chemical and exposure aspects, that constitute a concern for consumer safety, as well as to complete previously inconclusive safety assessments.

\subsubsection{Other Relevant Documents}

In early 2020, the European Union Observatory for Nanomaterials (EUON) announced that all companies producing, using or importing nanoforms should be REACH (Registration, Evaluation, Authorization and Restriction of Chemicals) compliant registered. REACH is an EU Regulation issued in 2006 by the EC [106]. In December 2018, the EC updated Regulation 1907/2006 to include nanoforms [103].

\subsection{USA}

\subsubsection{Definition of Nanomaterial and Regulating Authorities}

Unlike in the EU, in the USA, the Food and Drug Administration (FDA) has not yet approved a regulatory definition for nanomaterials and has stated that "the current framework for safety assessment is sufficiently robust and flexible to be appropriate for a variety of materials, including nanomaterials" [19]. However, scientists from the USA implicitly define nanomaterials as ranging between 1 and $100 \mathrm{~nm}[15,21]$, based on the definition given by some important organizations, such as the International American Society for Testing and Materials (ASTM), which is recognized worldwide for the development of international standards. In 2006, the ASTM published the first formalized definition of nanotechnology: "any technology that measures, manipulates or incorporates materials and/or resources from 1 to $100 \mathrm{~nm}^{\prime \prime}$. This concept is very similar to the National Nanotechnology Initiative (NNI) definition: "nanotechnology is the development, understanding and control of materials at the nanoscale, ranging from 1 to $100 \mathrm{~nm}^{\prime \prime}$ [97].

In the USA, the FDA governs the use of nanotechnology in cosmetics [15] through the Federal Food, Drug, and Cosmetic Act (FFDCA) [98], which regulates a wide range of products besides cosmetics, including drugs and food [18]. The FDA has created the NNI and the Nanotechnology Task Force (NTF) to evaluate regulatory approaches for nanotechnology products [79]. In the USA, companies wishing to market cosmetics have a legal responsibility to ensure that their products and ingredients, including nanoscale materials, are safe and properly labeled [21]. Unlike the EU, in the USA, cosmetic ingredients do not need approval from regulatory agencies to be marketed, with the exception of dyes [15]. Moreover, the FDA does not require manufacturers to explicitly mention on the label that their products contain nanomaterials, since it is believed that the particle size is not necessarily related to the toxicity profile, and the labeling may therefore confuse consumers. However, the FDA has some regulations and procedures that cosmetic manufacturers can voluntarily choose to comply with. In fact, the FDA, together with the Personal Care Products Council (PCPC), has developed regulations on the voluntary registration of cosmetic ingredients and the reporting of adverse reactions. This occurs through the Voluntary Cosmetic Registration Program (VCRP). Through this program, manufacturers can be updated as to materials with known risks and, thus, remove them from their finished products. 


\subsubsection{FDA Released Documents}

In June 2014, the FDA published three comprehensive guidance documents concerning the safety issues of nanotechnology: two of them are related to cosmetics. They do not establish legally taxable responsibilities, but only recommendations [18].

The first is "Considering whether an FDA-Regulated Product Involves the Application of Nanotechnology" [100]. Accordingly, two points are identified that should be used to assess whether FDA-regulated products, including cosmetics, involve the application of nanotechnology. They concern both the size of the particles and the properties/phenomena depending on size: (1) if "a material or final product is designed to have at least one external dimension, or internal or surface structure, in the nanoscale range (approximately $1 \mathrm{~nm}$ to $100 \mathrm{~nm}$ )"; (2) if "a material or final product is designed to exhibit properties or phenomena, including physical or chemical properties or biological effects, which are attributable to its size, even if these dimensions are outside the nanoscale range, down to one micrometer (1000 nm)". The second point is very important because nanomaterial properties, which are relevant for safety, efficacy, performance, quality evaluation, public health impact and product regulatory status, can also be attributed to materials with one or more dimensions exceeding the 1-100 nm range [100].

The second document is the "Guidance for Industry-Safety of Nanomaterials in Cosmetic Products" [102]; safety should be assessed by characterizing the nanomaterial itself and evaluating a wide range of chemical and physical properties. The FDA stressed the importance of particle characterization in terms of: surface properties, morphological characteristics, other physical properties (i.e., solubility), agglomeration and dimensional distribution, possible presence of impurities [6,79]. Considerations as to the toxicology and absorption, distribution, metabolism and excretion (ADME) of nanomaterials in cosmetics can be obtained by considering the routes of exposure, uptake/absorption and toxicity tests. The exposure assessment for nanomaterials follows a procedure that is similar to the one for non-nano ingredients [6]. If necessary, traditional tests must be modified and new alternative methods may need to be developed as nanomaterial solubility can affect the suitability of a traditional method. Therefore, the FDA suggests adjusting traditional tests for insoluble or partially soluble nanomaterials, which is a rather common occurrence as nanoparticles frequently clump together, forming larger insoluble agglomerates [102].

\subsection{Commonwealth Countries}

Health Canada considers a nanomaterial "any substance or product manufactured and any component material, ingredient, device or structure if: (1) it is comprised within the nanometric dimensions in at least one external dimension, or has an internal dimension or surface structure within nanoscale, or (2) it is smaller or larger than the nanoscale in all dimensions, but exhibits one or more properties/phenomena of the nanoforms". According to the Foods and Drugs Act, cosmetic products containing ingredients that are harmful to health should not be marketed. In 2007, Health Canada drew up a list of hazardous cosmetic ingredients, specifically a list of restricted or prohibited ingredients in cosmetics [79].

In Australia, the National Industry Chemicals Notification and Assessment Scheme (NICNAS) regulates the safety of ingredients in cosmetics and personal-care products, while sunscreens are regulated by the Therapeutic Goods Administration (TGA), and therefore considered as drugs. Neither of these associations, however, distinguishes between nanoparticles and bulk materials [22]. In Australia the definition of nanomaterial is provided by the NICNAS as: "industrial material intentionally produced, manufactured or designed to have specific properties or a specific composition and one or more dimensions typically between 1 and $100 \mathrm{~nm}^{\prime \prime}$. As required by the TGA, all chemical ingredients, including natural ones, are regulated as industrial chemicals under the "Industrial Chemicals Notification and Assessment Act 1989" [79].

In New Zealand, the definition of nanomaterial is the same as in the EU. However, the adoption of a labeling system for nanomaterials that is similar to that in the EU, 
prior to international harmonization of the definition, would undermine the industry's ability to standardize labels with other major markets, such as the USA and Australia, and thus inhibit trade and business opportunities. Therefore, according to the New Zealand authorities, the request for cosmetic labeling that explicitly refers to the presence of a nanomaterial should be temporarily set aside [79].

\subsection{Other Countries}

In Brazil, there are no regulations that are specific for nanomaterials and nanotechnologies. In 2012, ANVISA (National Agency for Sanitary Vigilance) promoted a debate on nanotechnology and security surveillance. In 2013, the Internal Committee of Nanotechology (CIN) was established with the aim of verifying the current understanding of nanomaterials. They prepared a document with the actions and regulatory policies on nanotechnologies present in other countries and suggested alternative guidelines and regulatory policies. [97].

In India, cosmetics are regulated by Schedule " $S$ " of the Drugs and Cosmetics Act 1940 \& Rules 1945, but there are no special provisions for assessing the safety or quality of cosmetics that contain nanomaterials [21]. The Bureau of Indian Standards (BIS) has established a special committee known as the "Nanotechnology Sectional Committee", which is made up of 33 members from various research organizations and companies. This committee works for the standardization of nanotechnology regulations [79].

In China, cosmetic products are classified into two categories: ordinary and intended for a special use. Each of these requires a different type of license from the State Food and Drug Administration (SFDA). The latter have to undergo safety and health quality tests such as microbiological, toxicological, chronic toxicity, carcinogenic tests, and safefor-human-use trials. For the marketing of cosmetics, a hygiene license or record-keeping certificate from the Health Administration Department of the State Council-SFDA must be obtained [78].

\section{Safety Concerns}

Although the unique properties of nanomaterials make them desirable as they can perform certain cosmetic functions, they may also represent a risk for consumer health. The concern that a potential health risk may be caused by insoluble nanoparticles is indeed a much debated topic in scientific literature, and this is mainly due to conflicting results and a lack of long-term toxicological studies [107-111]. The route of exposure plays a predominant role. The main route of exposure, as far as cosmetics are concerned, is cutaneous, but there are still uncertainties regarding the possibility that nanomaterials can penetrate through the stratum corneum and reach the vital layers. However, even if literature studies suggest generally limited skin absorption, this may increase in the case of damaged skin. Moreover, in safety assessment, special attention should also be paid to sprays or aerosols that contain nanomaterials, since exposure by inhalation is possible. Ingestion, on the other hand, can occur in the case of the use of cosmetic products that are applied to the mouth area (e.g., lipsticks), or through an involuntary transfer from hand to mouth [6].

The main evidence for the safety concerns about nanomaterials derives from the EU, since it has the most restrictive rules. Here, a nanomaterial refers to "any insoluble or biopersistent material". This term could also refer to materials that are water-insoluble and biodegradable, especially with regards to those that consist of lipids (such as vesicles, SLN, NLC, etc.). However, these systems, due to their chemical nature and their similarity with physiological lipids present in the stratum corneum, are able to fuse with cell membranes, and are therefore considered soluble materials. The legislation specifically regulates those insoluble and biopersistent materials, for which there are greater toxicological concerns. Within this context, according to Regulation $1223 / 2009$, by 11 January 2014, the EC made available a catalog of all nanomaterials used in cosmetic products, including those used as colorants, preservatives and UV filters in a separate section, indicating the categories 
of cosmetic products and reasonably foreseeable exposure conditions. Subsequently, this catalog is regularly updated and made publicly available [57]. The latest updated catalog provided by the EC consists of 29 nanomaterials and dates back to November 2019. This catalog is provided solely for consumer information, meaning that not all listed products are necessarily authorized [6], and is based on information that is electronically transmitted to the CPNP by the responsible person [15,112]. It should be noted that many of the listed substances are also registered under the REACH [6]. Of these, the EC has so far authorized the use of the following nanomaterials: UV filters containing nano- $\mathrm{TiO}_{2}$ [113-115], nano$\mathrm{ZnO}$ [116], Methylene Bis-Benzotriazolyl Tetramethylbutylphenol (MBBT) [117,118] and Tris-Biphenyl Triazine [119]. The use of nano-Carbon black [120] as a colorant in cosmetic products is also allowed [6,15]. Accordingly, the Annexes of EC Regulation 1223/2009 have been updated, with the corresponding limitations of use. On the other hand, there are some nanomaterials (Nano-hydroxyapatite, Colloidal Silver, Silica, Styrene/Acrylate Copolymer, Colloidal Copper) for which the SCCS has expressed negative opinions, concluding that its use should be avoided in cosmetic products, or an inconclusive report due to a lack of data [121-127]. The most relevant safety concerns for nanomaterials employed in cosmetic products, for which a written opinion has been released by the SCCS, are summarized in Table 6. 


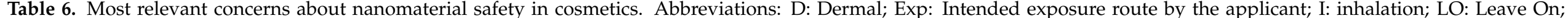

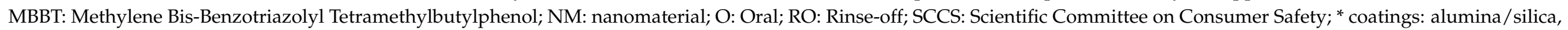

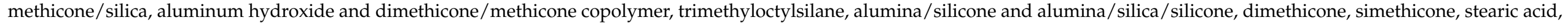
glycerol, dimethoxydiphenylsilane, triethoxycaprylylsilane, cetyl phosphate, manganese dioxide or triethoxycaprylylsilane.

\begin{tabular}{|c|c|c|c|c|c|c|c|}
\hline NM & Intended Use by the Applicant & Exp & $\begin{array}{l}\mathrm{LO} / \\
\mathrm{RO}\end{array}$ & $\begin{array}{c}\text { Safety } \\
\text { Concerns }\end{array}$ & $\begin{array}{l}\text { SCCS } \\
\text { Opinion }\end{array}$ & Justification & Ref \\
\hline $\mathrm{Nano}^{-\mathrm{TiO}_{2}}$ & UV filter in sunscreens & $\begin{array}{l}\mathrm{D} / \\
\mathrm{O} / \\
\mathrm{I}\end{array}$ & $\begin{array}{l}\mathrm{LO} / \\
\mathrm{RO}\end{array}$ & $\begin{array}{l}\text { Inhalation exposure } \\
\text { could lead to lung } \\
\text { inflammatory response } \\
\text { and potential } \\
\text { carcinogenicity }\end{array}$ & $\begin{array}{ll}\text { - } & \text { Positive for the use up to } \\
& 25 \% \text { concentration } \\
- & \text { Positive for coated } \mathrm{TiO}_{2} * \\
\text { - } & \text { Inconclusive for spray } \\
\text { applications }\end{array}$ & $\begin{array}{l}\text { Lack of dermal absorption after } \\
\text { application to healthy, intact skin }\end{array}$ & [113-115] \\
\hline Nano-ZnO & $\begin{array}{l}\text { UV filter in sunscreens and } \\
\text { colorant in dermally-applied } \\
\text { products }\end{array}$ & $\begin{array}{l}\mathrm{D} / \\
\mathrm{O} / \\
\mathrm{I}\end{array}$ & $\begin{array}{l}\mathrm{LO} / \\
\mathrm{RO}\end{array}$ & $\begin{array}{l}\text { Lung inflammation } \\
\text { after inhalation }\end{array}$ & $\begin{array}{ll}\text { - } & \text { Positive for the use as a } \\
\text { - } & \text { UV filter in sunscreens } \\
\text { - } & \text { concentration } \\
\text { - } & \text { Inconclusive for the use as } \\
\text { - } & \text { a colorant } \\
\text { Negative for spray } \\
\text { products }\end{array}$ & 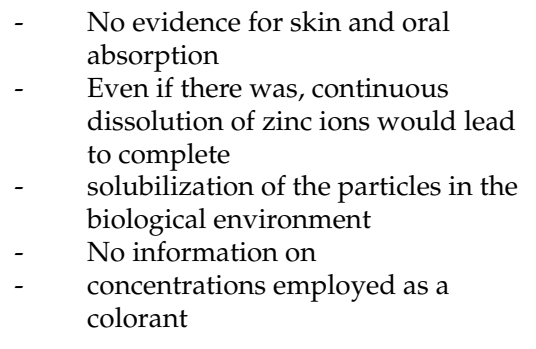 & [116] \\
\hline $\begin{array}{l}\text { Nano-MBBT } \\
(120 \mathrm{~nm})\end{array}$ & $\begin{array}{l}\text { UV filter in sunscreens, day care } \\
\text { and whitening products }\end{array}$ & $\begin{array}{l}\mathrm{D} / \\
\mathrm{O}\end{array}$ & $\begin{array}{l}\mathrm{LO} / \\
\mathrm{RO}\end{array}$ & $\begin{array}{l}\text { Inhalation } \\
\text { toxicity }\end{array}$ & $\begin{array}{ll}- & \text { Positive in concentrations } \\
- & \text { up to } 10 \% \\
- & \text { Caution required in case } \\
\text { of inhalation exposure } \\
\text { (the opinion does not } \\
\text { apply in this case) }\end{array}$ & $\begin{array}{l}\text { No concern for the dermal application } \\
\text { with regards to the systemic effects }\end{array}$ & {$[117,118,128]$} \\
\hline Tris-Biphenyl Triazine & $\begin{array}{l}\text { UV filter in sunscreens and } \\
\text { dermallyapplied products }\end{array}$ & $\begin{array}{c}\mathrm{D} / \\
\mathrm{I}\end{array}$ & $\mathrm{LO}$ & $\begin{array}{l}\text { Strong inflammatory } \\
\text { response in the lung } \\
\text { through inhalation } \\
\text { exposure }\end{array}$ & $\begin{array}{l}\text { Positive up to } 10 \% \\
\text { concentration, for the } \\
\text { uncoated form with a } \\
\text { median particle } \\
\text { size }>80 \mathrm{~nm} \\
\text { Inconclusive for spray } \\
\text { applications }\end{array}$ & $\begin{array}{l}\text { Lack of dermal absorption of the material } \\
\text { in insoluble particulate form }\end{array}$ & [119] \\
\hline
\end{tabular}


Table 6. Cont.

\begin{tabular}{|c|c|c|c|c|c|c|c|}
\hline NM & Intended Use by the Applicant & Exp & $\begin{array}{l}\text { LO/ } \\
\text { RO }\end{array}$ & $\begin{array}{l}\text { Safety } \\
\text { Concerns }\end{array}$ & $\begin{array}{l}\text { SCCS } \\
\text { Opinion }\end{array}$ & Justification & Ref \\
\hline $\begin{array}{l}\text { Nano-Carbon black } \\
(20 \mathrm{~nm} \text { or greater })\end{array}$ & $\begin{array}{l}\text { Colorant in skin products up to } \\
0.001 \%\end{array}$ & $\begin{array}{l}\mathrm{D} / \\
\mathrm{O}\end{array}$ & $\begin{array}{l}\mathrm{LO} / \\
\mathrm{RO}\end{array}$ & $\begin{array}{l}\text { Toxicity, inflammation } \\
\text { and altered } \\
\text { phagocytosis in human } \\
\text { monocytes }\end{array}$ & $\begin{array}{ll} & \text { Positive } \\
\text { - } & \text { at a concentration up to } \\
10 \% \\
\text { - } \quad \text { The opinion does not } \\
\text { apply to products entailed } \\
\text { with inhalation exposure }\end{array}$ & $\begin{array}{l}\text { General lack of skin absorption and } \\
\text { no risk of adverse effects after } \\
\text { application to healthy, intact skin for } \\
\text { nanoparticles } \geq 20 \mathrm{~nm} \text { (the opinion } \\
\text { applies only to such scaled } \\
\text { nanomaterials) }\end{array}$ & {$[120,129]$} \\
\hline $\begin{array}{c}\text { Nano } \\
\text { hydroxyapatite }\end{array}$ & $\begin{array}{l}\text { Toothpastes, teeth whiteners } \\
\text { and mouthwashes up to } 10 \%\end{array}$ & $\mathrm{O}$ & $\mathrm{RO}$ & $\begin{array}{l}\text { Cytotoxicity, induction } \\
\text { of oxidative stress, } \\
\text { apoptosis, and } \\
\text { inflammatory responses }\end{array}$ & $\begin{array}{l}\text { Negative/ } \\
\text { inconclusive }\end{array}$ & $\begin{array}{l}\text { Needle-shaped nano-hydroxyapatite } \\
\text { should not be used in cosmetics } \\
\text { No sufficient evidence for the other } \\
\text { forms of nano-hydroxyapatite }\end{array}$ & {$[121,122,130]$} \\
\hline Colloidal Ag & $\begin{array}{l}\text { Toothpastes up to } 1 \% \\
\text { Skin care products up to } 1 \%\end{array}$ & $\mathrm{O}$ & $\begin{array}{l}\mathrm{RO} \\
\mathrm{LO} / \\
\mathrm{RO}\end{array}$ & $\begin{array}{c}\text { Much of the } \\
\text { information provided } \\
\text { by the applicant turned } \\
\text { out not to be relevant } \\
\text { for safety assessment }\end{array}$ & $\begin{array}{l}\text { Negative/ } \\
\text { inconclusive }\end{array}$ & $\begin{array}{l}\text { Available information insufficient } \\
\text { for a conclusion } \\
\text { Attention to the possible presence of } \\
\text { ionic Ag in different types of } \\
\text { finished cosmetic products }\end{array}$ & [123] \\
\hline Nano-Silica & $\begin{array}{l}\text { Absorbent \& anti-caking agent, } \\
\text { controlled release of active } \\
\text { compounds }\end{array}$ & $\begin{array}{l}\mathrm{D} / \\
\mathrm{O} / \\
\mathrm{I}\end{array}$ & $\begin{array}{l}\mathrm{LO} / \\
\mathrm{RO}\end{array}$ & $\begin{array}{l}\text { Nanoparticles might } \\
\text { penetrate the skin and } \\
\text { end up in internal } \\
\text { organs or the } \\
\text { bloodstream-where } \\
\text { they might be toxic }\end{array}$ & $\begin{array}{l}\text { Negative/ } \\
\text { inconclusive }\end{array}$ & $\begin{array}{l}\text { No proof that nanosilica penetrates the } \\
\text { skin or is toxic, but also no enough } \\
\text { evidence to rule out those possibilities }\end{array}$ & {$[124,125]$} \\
\hline $\begin{array}{l}\text { Styrene/Acrylate } \\
\text { Copolymer }\end{array}$ & $\begin{array}{l}\text { Carrier for other bioactive } \\
\text { compounds }\end{array}$ & $\mathrm{D}$ & LO & $\begin{array}{l}\text { Potential accumulation } \\
\text { of the encapsulated } \\
\text { substances to } \\
\text { unintended parts of the } \\
\text { body }\end{array}$ & $\begin{array}{l}\text { Negative/ } \\
\text { inconclusive }\end{array}$ & $\begin{array}{l}\text { No sufficient evidence for the safety } \\
\text { related to nano-scale styrene/acrylates as } \\
\text { such or as a carrier for bioactive substances }\end{array}$ & [126] \\
\hline Colloidal Cu & $\begin{array}{c}\text { Oral uses } \\
\text { (mouth wash) }\end{array}$ & $\mathrm{O}$ & $\mathrm{RO}$ & $\begin{array}{c}\text { Possible systemic } \\
\text { uptake of } \mathrm{Cu} \\
\text { nanoparticles with } \\
\text { potential accumulation } \\
\text { in certain organs; } \\
\text { potential } \\
\text { mutagenic/genotoxic } \\
\text { and immuno- } \\
\text { toxic/nephrotoxic } \\
\text { effects }\end{array}$ & $\begin{array}{l}\text { Negative/ } \\
\text { inconclusive }\end{array}$ & $\begin{array}{l}\text { Further safety evaluation are needed due } \\
\text { to the relevant potential toxicological risks }\end{array}$ & [127] \\
\hline
\end{tabular}




\section{Conclusions}

Since the end of eighties, when nanosystems were introduced in cosmetic products, the worldwide nano-market has been consistently extensive due to the materials' claimed advantages, including relevant cosmetic functions, such as the improvement of the intrinsic properties of the cosmetic product itself and increased skin retention of the loaded compounds. However, there is still no unambiguous definition-globally-that identifies nanomaterials as cosmetic ingredients, meaning that each country follows its own definition and legislation. Indeed, the main evidence for the safety concerns about nanomaterials in cosmetics comes from the EU, since it has the most restrictive regulations. Accordingly, in order to determine whether a nanomaterial is safe for human health and the environment, a series of parameters should be evaluated, and, in particular, advanced physico-chemical characterizations should be performed. However, it should be noted that the main safety concerns arise from accidental uptake through an unwanted exposure route, while the poor dermal permeation of insoluble and biopersistent nanomaterials limits their potential toxic effects. This aspect could also be important for dermal drug-delivery systems, given that, as previously mentioned, they have a longer time-to-market than cosmetics due to long-lasting clinical studies. Indeed, current disclosures as to poor absorption through the skin that are relevant for the safety assessment of cosmetic nanomaterials could pave the way, in the future, for a standardized safety assessment for nano-structured pharmaceutical formulations for skin applications.

Author Contributions: Conceptualization, E.U.; investigation, C.R.; writing-original draft preparation, C.F.; writing-review and editing, S.G.; supervision, L.B. All authors have read and agreed to the published version of the manuscript.

Funding: This research was funded by University of Turin, Ricerca Locale 2018-2019.

Acknowledgments: The authors thank Dale Lawson for his English revision.

Conflicts of Interest: The authors declare no conflict of interest.

\section{References}

1. Gupta, S.; Bansal, R.; Gupta, S.; Jindal, N.; Jindal, A. Nanocarriers and nanoparticles for skin care and dermatological treatments. Indian Dermatol. Online J. 2013, 4, 267-272. [CrossRef]

2. Pastrana, H.; Avila, A.; Tsai, C.S.J. Nanomaterials in Cosmetic Products: The challenges with regard to current legal frameworks and consumer exposure. Nanoethics 2018, 12, 123-137. [CrossRef]

3. Bilal, M.; Iqbal, H.M.N. New insights on unique features and role of nanostructured materials in cosmetics. Cosmetics 2020, 7, 24. [CrossRef]

4. Antunes, A.F.; Pereira, P.; Reis, C.; Rijo, P.; Reis, C. Nanosystems for Skin Delivery: From Drugs to Cosmetics. Curr. Drug Met. 2017, 18, 412-425. [CrossRef]

5. $\quad$ Roberts, M.S.; Mohammed, Y.; Pastore, M.N.; Namjoshi, S.; Yousef, S.; Alinaghi, A.; Haridass, I.N.; Abd, E.; Leite-Silva, V.R.; Benson, H.; et al. Topical and cutaneous delivery using nanosystems. J. Control. Release 2017, 247, 86-105. [CrossRef] [PubMed]

6. Fytianos, G.; Rahdar, A.; Kyzas, G.Z. Nanomaterials in cosmetics: Recent updates. Nanomaterials 2020, 10, 979. [CrossRef] [PubMed]

7. ISO. Nanotechnologies_Vocabulary_Part 1: Core Terms; ISO/TS 80004-1; International Organization for Standardization: Geneva, Switzerland, 2010. Available online: https://www.iso.org/obp/ui/\#iso:std:iso:ts:80004:-1:ed-2:v1:en (accessed on 20 August 2021).

8. ISO. Technical Specification: Nanotechnologies_Terminology and Definitions for Nano-Objects—Nanoparticle, Nanofibre and Nanoplate; ISO/TS 80004-2:2008; International Organization for Standardization: Geneva, Switzerland, 2008. Available online: https: //www.iso.org/obp/ui/\#iso:std:54440:en (accessed on 20 August 2021).

9. Boverhof, D.R.; Bramante, C.M.; Butala, J.H.; Clancy, S.F.; Lafranconi, M.; West, J.; Gordon, S.C. Comparative assessment of nanomaterial definitions and safety evaluation considerations. Regul. Toxicol. Pharmacol. 2015, 73, 137-150. [CrossRef]

10. Zhou, H.; Luo, D.; Chen, D.; Tan, X.; Bai, X.; Liu, Z.; Yang, X.; Liu, W. Current Advances of Nanocarrier Technology-Based Active Cosmetic Ingredients for Beauty Applications. Clin. Cosmet. Investig. Dermatol. 2021, 14, 867-887. [CrossRef] [PubMed]

11. Battaglia, L.; Ugazio, E. Lipid nano- and microparticles: An overview of patent-related research. J. Nanomat. 2019. [CrossRef]

12. Mainard, A.D.; Aitken, R.J.; Butz, T.; Colvin, V.; Donaldson, K.; Oberdörster, G.; Philbert, M.A.; Ryan, J.; Seaton, A.; Stone, V.; et al. Safe handling of nanotechnology. Nature 2006, 444, 267-269. [CrossRef]

13. Etheridge, M.L.; Campbell, S.A.; Erdman, A.G.; Haynes, C.L.; Wolf, S.M.; McCullough, J. The big picture on nanomedicine: The state of investigational and approved nanomedicine products. Nanomedicine 2013, 9, 1-14. [CrossRef] [PubMed] 
14. Saleh, T.A. Nanomaterials: Classification, properties, and environmental toxicities. Environ. Technol. Innov. 2020, 20, 101067. [CrossRef]

15. Santos, A.C.; Morais, F.; Simoes, A.; Pereira, I.; Sequieira, J.A.D.; Pereira-Silva, M.; Veiga, F.; Ribeiro, A. Nanotechnology for the development of new cosmetic formulations. Exp. Opin. Drug. Del. 2019, 16, 313-330. [CrossRef] [PubMed]

16. Ijaz, I.; Gilani, E.; Nazir, A.; Bukhari, A. Detail review on chemical, physical and green synthesis, classification, characterizations and applications of nanoparticles. Green Chem. Lett. Rev. 2020, 13, 223-245. [CrossRef]

17. Teleanu, D.M.; Chircov, C.; Grumezescu, A.M.; Teleanu, R.I. Neurotoxicity of nanomaterials: An up-to-date overview. Nanomaterials 2019, 9, 96. [CrossRef]

18. Ajazzuddin, M.; Jeswani, G.; Jha, A.K. Nanocosmetics: Past, present and future trends. Recent Pat. Nanomed. 2015, 5, 3-11. [CrossRef]

19. Schneider, S.L.; Lim, H.W. A review of organic UV filters zinc oxide and titanium dioxide. Photodermatol. Photoimmunol. Photomed. 2019, 35, 442-446. [CrossRef] [PubMed]

20. Srinivas, K. The current role of nanomaterials in cosmetics. J. Chem. Pharm. Res. 2016, 8, 906-914.

21. Nanda, S. Nanocosmeceuticals: Retrospect, precepts and prospects. Pharma. Times 2018, 50, 73-78.

22. Raj, S.; Jose, S.; Sumod, U.S.; Sabitha, M. Nanotechnology in cosmetics: Opportunities and challenges. J. Pharm. Bioallied. Sci. 2012, 4, 186-193. [CrossRef]

23. Gupta, S.R.N. Exploration of various classes of nanoparticles used in cosmetic applications. Int. Res. J. Sci. Eng. 2016, 4, 91-97.

24. Yang, S.; Liu, L.; Han, J.; Tang, Y. Encapsulating plant ingredients for dermocosmetic application: An update review of delivery systems and characterization techniques. Int. J. Cosmet. Sci. 2020, 42, 16-28. [CrossRef]

25. Pardeike, J.; Hommoss, A.; Müller, R.H. Lipid nanoparticles (SLN, NLC) in cosmetic and pharmaceutical dermal products. Int. J. Pharm. 2009, 366, 170-184. [CrossRef]

26. Chauhan, I.; Yasir, M.; Verma, M.; Singh, A.P. Nanostructured lipid carriers: A groundbreaking approach for transdermal drug delivery. Adv. Pharm. Bull. 2020, 10, 150-165. [CrossRef]

27. Müller, R.H.; Radtke, M.; Wissing, S.A. Solid lipid nanoparticles (SLN) and nanostructured lipid carriers (NLC) in cosmetic and dermatological preparations. Adv. Drug Del. Rev. 2002, 54, S131-S155. [CrossRef]

28. Lohani, A.; Verma, A. Vescicles: Potential nano carriers for the delivery of skin cosmetics. J. Cosmet Laser Ther. 2017, 19, 485-493. [CrossRef]

29. Fakhravar, Z.; Ebrahimnejad, P.; Daraee, H.; Akbarzadeh, A. Nanoliposomes: Synthesis methods and applications in cosmetics. J. Cosmet Laser Ther. 2016, 18, 174-181. [CrossRef] [PubMed]

30. Egbaria, K.; Weiner, N. Liposomes as a topical drug delivery system. Adv. Drug Del Rev. 1990, 5, 287-300. [CrossRef]

31. Hussain, A.; Singh, S.; Sharma, D.; Webster, T.J.; Shafaat, K.; Faruk, A. Elastic liposomes as novel carriers: Recent advances in drug delivery. Int. J. Nanomed. 2017, 12, 5087-5108. [CrossRef] [PubMed]

32. Blume, G. Flexible liposomes for topical applications in cosmetics. In Science and Application of Skin Delivery Systems; Wiechers, J.W., Ed.; Allured Publishing: Carol Stream, IL, USA, 2010.

33. Chen, S.; Hanning, S.; Falconer, J.; Locke, M.; Wen, J. Recent advances in non-ionic surfactant vesicles (niosomes): Fabrication, characterization, pharmaceutical and cosmetic applications. Eur. J. Pharm. Biopharm. 2019, 144, 18-39. [CrossRef]

34. Azmi, N.A.N.; Elgharbawy, A.A.M.; Motlagh, S.R.; Samsudin, N.; Salleh, H.M. Nanoemulsions: Factory for food, pharmaceutical and cosmetics. Processes 2019, 7, 617. [CrossRef]

35. Özgün, S. Nanoemulsions in cosmetics. Nanomaterials and Nanotechnology Lecture Project Report; Anadolu University: Eskişehir, Turkey, 2013.

36. Sharma, S.; Sarangdevot, K. Nanoemulsions for cosmetics. Int. J. Adv. Res. Biol. Sci. 2012, 2, 408-415.

37. Lopes, L.B. Overcoming the cutaneous barrier with microemulsions. Pharmaceutics 2014, 6, 52-77. [CrossRef]

38. Spicer, P. Cubosome processing: Industrial nanoparticle technology development. Chem. Eng. Res. Des. 2005, 83, 1283-1286. [CrossRef]

39. Bahamonde-Norambuena, D.; Molina-Pereira, A.; Cantin, M.; Muñoz, M.; Zepeda, K.; Vilos, C. Polymeric nanoparticles in dermocosmetic. Int. J. Morphol. 2015, 33, 1563-1568. [CrossRef]

40. Guterres, S.S.; Alves, M.P.; Pohlmann, A.R. Polymeric nanoparticles, nanospheres and nanocapsules, for cutaneous applications. Drug Target Insights 2017, 2, 147-157.

41. Kokura, S.; Handa, O.; Takagi, T.; Ishikawa, T.; Naito, Y.; Yoshikawa, T. Silver nanoparticles as a safe preservative for use in cosmetics. Nanomed. Nanotechnol. Biol. Med. 2010, 6, 570-574. [CrossRef] [PubMed]

42. Pulit-Prociak, J.; Grabowska, A.; Chwastowski, J.; Majka, T.M.; Banach, M. Safety of the application of nanosilver and nanogold in topical cosmetic preparations. Colloids Surf. B Biointerfaces 2019, 183, 110416. [CrossRef]

43. Sharma, S.; Sharma, R.K.; Gaur, K.; Càtala Torres, J.F.; Loza-Rosas, S.A.; Torres, A.; Saxena, M.; Julin, M.; Tinoco, A.D. Fueling a hot debate on the application of $\mathrm{TiO}_{2}$ nanoparticles in sunscreens. Materials 2019, 12, 2317. [CrossRef] [PubMed]

44. Nafisi, S.; Schafer-Korting, M.; Maibach, H.I. Measuring silica nanoparticles in the skin. In Agache's Measuring the Skin; Humbert, P., Fanian, F., Maibach, H., Agache, P., Eds.; Springer: Cham, Switzerland, 2017. [CrossRef]

45. Mebert, A.M.; Baglole, C.J.; Desimone, M.F.; Maysinger, D. Nanoengineered silica: Properties, applications and toxicity. Food Chem. Toxicol. 2017, 109, 753-770. [CrossRef]

46. Ramis, J.M.; Coelho, C.C.; Córdoba, A.; Quadros, P.A.; Monjo, M. Safety assessment of nano-hydroxyapatite as an oral care ingredient according to the EU cosmetics Regulation. Cosmetics 2018, 5, 53. [CrossRef] 
47. Bordea, I.R.; Candrea, S.; Alexescu, G.T.; Brand, S.; Baciut, M.; Baciut, G.; Lucaciu, O.; Dinu, C.M.; Todeaf, D.A. Nanohydroxyapatite use in dentistry: A systematic review. Drug Metab Rev. 2020, 52, 319-332. [CrossRef]

48. Lens, M. Use of fullerenes in cosmetics. Recent Pat. Biotechnol. 2009, 3, 118-123. [CrossRef] [PubMed]

49. Kuche, K.; Maheshwari, R.; Tambe, V.; Mak, K.-K.; Jogi, H.; Raval, N.; Pichika, M.; Tekade, R. Carbon nanotubes (CNTs) based advanced dermal therapeutics: Current trends and future potential. Nanoscale 2018, 10, 8911-8937. [CrossRef] [PubMed]

50. Monteiro-Riviere, N.A.; Inman, A.O. Challenges for assessing carbon nanomaterial toxicity to the skin. Carbon 2006, 44 , 1070-1078. [CrossRef]

51. Contado, C. Nanomaterials in consumer products: A challenging analytical problem. Front. Chem. 2015, 3, 48. [CrossRef]

52. Chen, J.; Hu, L. Nanoscale delivery systems for nutraceutical: Preparation, application, characterization, safety, and future trends. Food Eng. Rev. 2020, 12, 14-31. [CrossRef]

53. SCCS. Guidance on the Safety Assessment of Nanomaterials in Cosmetics; SCCS/1611/19; Scientific Committee on Consumer Safety: Brussels, Belgium, 2019. Available online: https:/ / ec.europa.eu/health/sites/default/files/scientific_committees/consumer_ safety/docs/sccs_o_233.pdf (accessed on 15 July 2021).

54. Zielinska, A.; Carreirò, F.; Oliveira, A.M.; Neves, A.; Pires, B.; Nagasamy Venkatesh, D.; Durazzo, A.; Lucarini, M.; Eder, P.; Silva, A.M.; et al. Polymeric nanoparticles: Production, characterization, toxicology and ecotoxicology. Molecules 2020, 25, 3731. [CrossRef]

55. Yapar, E.A.; Inal, Ö. Nanomaterials and cosmetics. J. Pharm. Istanbul. Univ. 2012, 42, 43-70.

56. Karamanidou, T.; Bourganis, V.; Gatzogianni, G.; Tsouknidas, A. A Review of the EU's Regulatory Framework for the Production of Nano-Enhanced Cosmetics. Metals 2021, 11, 455. [CrossRef]

57. EC. Regulation on Cosmetic Products; 2009/1223/EU; European Commission: Brussels, Belgium. Available online: https:// ec.europa.eu/health/sites/default/files/endocrine_disruptors/docs/cosmetic_1223_2009_regulation_en.pdf (accessed on 15 July 2021).

58. Sharma, B.; Sharma, A. Future prospect of nanotechnology in development of anti-ageing formulations. Int. J. Pharm. Pharm. Sci. 2012, 4, 57-66.

59. Arora, N.; Agarwal, S.; Murthy, R.S. Latest technology advances in cosmaceuticals. Int. J. Pharm. Sci. Drug Res. 2012, 4, 168-182.

60. Miastkowska, M.; Lasoń, E.; Sikora, E.; Wolińska-Kennard, K. Preparation and Characterization of Water-Based Nano-Perfumes Nanomaterials 2018, 8, 981. [CrossRef] [PubMed]

61. Grimes, P.E. A Microsponge Formulation of Hydroquinone $4 \%$ and Retinol $0.15 \%$ in the Treatment of Melasma and Post Inflammatory Hyperpigmentation. Cutis 2004, 74, 362-368. [PubMed]

62. Singh, P.; Nanda, A. Enhanced sun protection of nano-sized metal oxide particles over conventional metal oxide particles: An in vitro comparative study. Int. J. Cosmet Sci. 2014, 36, 273-283. [CrossRef] [PubMed]

63. Schneider, M.; Stracke, F.; Hansen, S.; Schaefer, U.F. Nanoparticles and their interactions with the dermal barrier. Dermatoendocrinol 2009, 1, 197-206. [CrossRef]

64. Larese Filon, F.; Mauro, M.; Adami, G.; Bovenzi, M.; Crosera, M. Nanoparticles skin absorption: New aspects for a safety profile evaluation. Regul. Toxicol. Pharmacol. 2015, 72, 310-322. [CrossRef]

65. Liang, X.W.; Xu, Z.P.; Grice, J.; Zvyagin, A.V.; Roberts, M.S.; Liu, X. Penetration of nanoparticles into human skin. Curr. Pharm. Des. 2013, 19, 6353-6366. [CrossRef]

66. Wickett, R.R.; Visscher, M.O. Structure and function of the epidermal barrier. Am. J. Infect. Control. 2006, 34, S98-S110. [CrossRef]

67. Carrer, D.C.; Vermehren, C.; Bagatolli, L.A. Pig skin structure and transdermal delivery of liposomes: A two photon microscopy study. J. Control. Release 2008, 132, 12-20. [CrossRef]

68. Cevc, G. Lipid vesicles and other colloids as drug carriers on the skin. Adv. Drug Deliv. Rev. 2004, 56, 675-711. [CrossRef] [PubMed]

69. Cevc, G.; Vierl, U. Nanotechnology and the transdermal route: A state of the art review and critical appraisal. J. Control. Release 2010, 141, 277-299. [CrossRef] [PubMed]

70. Mojsiewicz-Pieńkowska, K.; Stachowska, E.; Krenczkowska, D.; Bazar, D.; Meijer, F. Evidence of Skin Barrier Damage by Cyclic Siloxanes (Silicones)—Using Digital Holographic Microscopy. Int. J. Mol. Sci. 2020, 21, 6375. [CrossRef] [PubMed]

71. Lapteva, M.; Santer, V.; Mondon, K.; Patmanidis, I.; Chiriano, G.; Scapozza, L.; Gurny, R.; Möller, M.; Kalia, Y.N. Targeted cutaneous delivery of cyclosporin A using micellar nanocarriers and the possible role of inter-cluster regions as molecular transport pathways. J. Control. Release 2014, 196, 9-18. [CrossRef] [PubMed]

72. Bugaj, A.M. Intradermal Delivery of Active Cosmeceutical Ingredients. In Novel Delivery Systems for Transdermal and Intradermal Drug Delivery; Donnelly, R.F., Singh, T.R.R., Eds.; Wiley: Hoboken, NJ, USA, 2015. [CrossRef]

73. Saraf, S.; Kaur, C.D.; Gupta, A.; Verma, N. Skin Targeting Approaches in Cosmetics. Indian J. Pharm. Educ. Res. 2019, 53, 577-594. [CrossRef]

74. Ascenso, A.; Simões, S.; Ribeiro, H. Carrier-Mediated Dermal Delivery: Applications in the Prevention and Treatment of Skin Disorders, Jenny Stanford Publishing: Boca Raton, FL, USA, 2017. Available online: https:/ / www.routledge.com/Carrier-Mediated-DermalDelivery-Applications-in-the-Prevention-and-Treatment/Ascenso-Ribeiro-Simoes/p/book/9789814745581 (accessed on 15 July 2021).

75. Mohanty, D.; Mounika, A.; Bakshi, V.; Akiful Haque, M.; Sahoo, C.K. Ethosomes: A Novel Approach for Transdermal Drug Delivery. Int. J. Chem. Tech. Res. 2018, 11, 219-226. [CrossRef] 
76. Wadher, K.; Pounikar, S.D.; Trivedi, S.; Umekar, M. Ethosome: A Novel Vesicular Carrier. Int. J. Innov. Res. Adv. Stud. 2018, 5, 13-20. Available online: https:/ / www.ijiras.com/2018/Vol_5-Issue_7/paper_3.pdf (accessed on 15 July 2021).

77. Ahmadi Ashtiani, H.R.; Bishe, P.; Lashgari, N.; Nilforoushzadeh, M.A.; Zare, S. Liposomes in Cosmetics. J. Skin Stem Cell 2016, 3, e65815. [CrossRef]

78. Kaul, S.; Gulati, N.; Verma, D.; Mukherjee, S.; Nagaich, U. Role of nanotechnology in cosmeceuticals: A Review of Recent Advances. J. Pharm. 2018, 2018, 3420204. [CrossRef]

79. Madan, K.; Nanda, S. Nanotechnology driven cosmetic products: Commercial and regulatory milestones. Appl. Clin. Res. Clin. Trials Regul. Aff. 2018, 5, 112-121.

80. Kuenen, J.; Pomar-portillo, V.; Vilchez, A.; Visschedijk, A.; van der Gon, H.D.; Vázquez-Campos, S.; Nowack, B.; Adam, V. Inventory of country-specific emissions of engineered nanomaterials throughout the life cycle. Environ. Sci. Nano 2020, 7 , 3824-3839. [CrossRef]

81. Dhapte-Pawar, V.; Kadam, S.; Saptarsi, S.; Kenjale, P.P. Nanocosmeceuticals: Facets and aspects. Future Sci. OA 2020, 6, FSO613. [CrossRef] [PubMed]

82. Talegaonkar, S.; Rai, M. Nanoformulations in Human Health Challenges and Approaches; Springer: Cham, Switzerland, 2017; ISBN 978-3-030-41860-1. Available online: https:/ / www.springer.com/gp/book/9783030418571 (accessed on 15 July 2021).

83. Rahiman, A.A.; Krishnan, K.; Srelekshmi, A.S.; Arjum, K.K.; Nair, S.C. Novasome: A pionering advancement in vesicular drug delivery. Int. J. Appl. Pharm. 2021, 13, 59-64. [CrossRef]

84. Sonawane, R.O.; Deshmukh, A.S.; Mangrule, U.E.; Shinde, S.A.; Mahajan, H.S. Nanotechnology as a marketing future. World J. Pharm. Res. 2020, 9, 889-903.

85. Lohani, A.; Verma, A.; Joshi, H.; Yadav, N.; Karki, N. Nanotechnology-based cosmeceuticals. ISRN Dermatol. 2014, 843687. [CrossRef]

86. Najibfard, K.; Ramalingam, K.; Chedjieu, I.; Amaechi, B.T. Remineralization of early caries by a nano-hydroxyapatite dentifrice. J. Clin. Dent. 2011, 22, 139-143. [PubMed]

87. Nanotechnology Product Database. Available online: https://product.statnano.com (accessed on 15 July 2021).

88. Consumer Products Inventory. Available online: https://www.nanotechproject.tech/cpi (accessed on 15 July 2021).

89. Vance, M.E.; Kuiken, T.; Vejerano, E.P.; McGinnis, S.P.; Hochella, M.F., Jr.; Tejeski, D.; Hull, M.S. Nanotechnology in the real world: Redeveloping the nanomaterial consumer products inventory. Beilstein. J. Nanotechnol. 2015, 6, 1769-1780. [CrossRef] [PubMed]

90. Berube, D.M.; Searson, E.M.; Morton, T.S.; Cummings, C.L. Project on emerging nanotechnologies-Consumer product inventory evaluated. Nanotechnol. Law Bus. 2010, 7, 152-163.

91. Tasleem, A.; Nuzhatun, N.; Syed, S.A.; Sheikh, S.; Raheel, M.; Muzafar, R.S. Therapeutic and diagnostic applications of nanotechnology in dermatology and cosmetics discovery. J. Nanomed. Biother. Discov. 2015, 5, 1-10.

92. Scherer Santos, J. Nanocosmetics: Production, Characterization, and Performance Improvement. In Beauty-Cosmetic Science, Cultural Issues and Creative Developments; Levine, M.P., Santos, J.S., Eds.; IntechOpen: London, UK, 2020. Available online: https:/ / www.intechopen.com/chapters/73171 (accessed on 15 July 2021).

93. Netto, G.; Jose, J. Development, characterization, and evaluation of sunscreen cream containing solid lipid nanoparticles of silymarin. J. Cosmet Dermatol. 2018, 17, 1073-1083. [CrossRef]

94. Carlotti, M.E.; Battaglia, L.; Ugazio, E.; Gallarate, M.; Debernardi, F. Study on the release properties and stability of o/w emulsions containing salicylic acid and zinc oxide. J. Drug Del. Sci. Technol. 2004, 14, 119-126. [CrossRef]

95. Dréno, B.; Alexis, A.; Chuberre, B.; Marinovich, M. Safety of titanium dioxide nanoparticles in cosmetics. J. Eur. Acad. Dermatol. Venereol. 2019, 33, 34-46. [CrossRef] [PubMed]

96. Patravale, V.B.; Mandawgade, S.D. Novel cosmetic delivery systems: An application update. Int. J. Cosm. Sci. 2008, 30, 19-33. [CrossRef]

97. Melo, A.; Amadeu, M.; Lancellotti, M.; Hollanda, L.; Machado, D. The role of nanomaterials in cosmetics: National and international legislative aspects. Química Nova 2015, 38, 599-603. [CrossRef]

98. FDA. Federal Food Drug and Cosmetic Act (FFDCA); Last revision 2018; Food and Drug Administration: Silver Spring, MD, USA, 2018. Available online: https://www.fda.gov/regulatory-information/laws-enforced-fda/federal-food-drug-and-cosmeticact-fdc-act (accessed on 15 July 2021).

99. EC. Recommendation on Nanomaterial Definition; 2011/696/EU; European Commission: Brussels, Belgium, 2011. Available online: https: / / eur-lex.europa.eu/LexUriServ/LexUriServ.do?uri=OJ:L:2011:275:0038:0040:en:PDF (accessed on 15 July 2021).

100. FDA. Considering Whether an FDA-Regulated Product Involves the Application of Nanotechnology; Food and Drug Administration: Silver Spring, MD, USA, 2014. Available online: https:/ / www.fda.gov/media/88423/download (accessed on 15 July 2021).

101. SCCS. The SCCS Notes of Guidance for the Testing of Cosmetic Ingredients and Their Safety Evaluation; 11th revision; SCCS/ 1628/21; Scientific Committee on Consumer Safety: Brussels, Belgium, 2021. Available online: https:/ / ec.europa.eu/health/sites/default/ files/scientific_committees/consumer_safety/docs/sccs_o_250.pdf (accessed on 20 August 2021).

102. FDA. Guidance for Industry—Safety of Nanomaterials in Cosmetic Products; Food and Drug Administration: Silver Spring, MD, USA, 2014. Available online: https:// www.fda.gov/media/83957/download (accessed on 15 July 2021). 
103. EC. Regulation Amending Regulation (EC) No 1907/2006 of the European Parliament and of the Council on the Registration, Evaluation, Authorisation and Restriction of Chemicals (REACH) As Regards Annexes I, III, VI, VII, VIII, IX, X, XI, and XII to Address Nanoforms of Substances; 1881/2018/EU; European Commission: Brussels, Belgium, 2018. Available online: https: / / eur-lex.europa.eu/legalcontent/EN/TXT/PDF/?uri=CELEX:32018R1881 (accessed on 15 July 2021).

104. SCCS. Guidance on the Safety Assessment of Nanomaterials in Cosmetics; SCCS/1484/12; Scientific Committee on Consumer Safety: Brussels, Belgium, 2012. Available online: https:/ / ec.europa.eu/health/scientific_committees/consumer_safety/docs/sccs_s_00 5.pdf (accessed on 15 July 2021).

105. SCCS. Scientific Advice on the Safety of Nanomaterials in Cosmetic; SCCS/1618/20; Scientific Committee on Consumer Safety: Brussels, Belgium, 2020. Available online: https:/ /ec.europa.eu/health/sites/default/files/scientific_committees/consumer_ safety/docs/sccs_o_239.pdf (accessed on 15 July 2021).

106. EC. Regulation on Registration, Evaluation, Authorization and Restriction of Chemical Substances (REACH); 1907/2006/EU; European Commission: Brussels, Belgium, 2006. Available online: https:/ / eur-lex.europa.eu/LexUriServ /LexUriServ.do?uri=OJ:L:2007: 136:0003:0280:EN:PDF (accessed on 15 July 2021).

107. Hubbs, A.F.; Mercer, R.R.; Benkovic, S.A.; Harkema, J.; Sriram, K.; Schwegler-Berry, D.; Goravanahally, M.P.; Nurkiewicz, T.R.; Castranova, V.; Sargent, L.M. Nanotoxicology-A pathologist's perspective. Toxicol. Pathol. 2011, 39, 301-324. [CrossRef]

108. Mogharabi, M.; Abdollahi, M.; Faramarzi, M.A. Toxicity of nanomaterials; An undermined issue. Daru 2014, 22, 59. [CrossRef] [PubMed]

109. Gebel, T.; Foth, H.; Damm, G.; Freyberger, A.; Kramer, P.J.; Lilienblum, W.; Röhl, C.; Schupp, T.; Weiss, C.; Wollin, K.M.; et al Manufactured nanomaterials: Categorization and approaches to hazard assessment. Arch. Toxicol. 2014, 88, 2191-2211. [CrossRef]

110. Zhang, X.; Li, W.; Yang, Z. Toxicology of nanosized titanium dioxide: An update. Arch. Toxicol. 2015, 89, 2207-2217. [CrossRef]

111. Nohynek, G.J.; Lademann, J.; Ribaud, C.; Michael, S.; Nohynek, G.J.; Roberts, M.S. Grey Goo on the skin? Nanotechnology, cosmetic and sunscreen safety. Crit. Rev. Toxicol. 2007, 37, 251-277. [CrossRef]

112. EC. Catalogue of Nanomaterials in Cosmetic Products Placed on the Market, as Notified to the European Commission by Responsible Persons, 2nd ed.; European Commission: Brussels, Belgium, 2019. Available online: https:/ / ec.europa.eu/growth/content/commissionpublishes-updated-catalogue-nanomaterials-used-cosmetics_en (accessed on 15 July 2021).

113. SCCS. Opinion on Titanium Dioxide (Nano Form); SCCS/1516/13; Scientific Committee on Consumer Safety: Brussels, Belgium, 2013. Available online: https://ec.europa.eu/health/scientific_committees/consumer_safety/docs/sccs_o_136.pdf (accessed on 15 July 2021).

114. SCCS. Opinion on Additional Coatings for Titanium Dioxide (Nano Form) as UV-Filter in Dermally Applied Cosmetic Products; SCCS/1580/16; Scientific Committee on Consumer Safety: Brussels, Belgium, 2016. Available online: https://ec.europa. eu/health/scientific_committees/consumer_safety/docs/sccs_o_202.pdf (accessed on 15 July 2021).

115. SCCS. Opinion on Titanium Dioxide (Nano Form) as UV-Filter in Sprays; SCCS/1583/17; Scientific Committee on Consumer Safety: Brussels, Belgium, 2018. Available online: https:/ / ec.europa.eu/health/sites/default/files/scientific_committees/consumer_ safety/docs/sccs_o_206.pdf (accessed on 15 July 2021).

116. SCCS. Opinion on Zinc Oxide (Nano Form); SCCS/1489/12; Scientific Committee on Consumer Safety: Brussels, Belgium, 2012. Available online: https:/ / ec.europa.eu/health/scientific_committees/consumer_safety/docs/sccs_o_103.pdf (accessed on 15 July 2021).

117. SCCS. Opinion on 2,2'-Methylene-bis-(6-(2H-benzotriazol-2-yl)-4-(1,1,3,3-tetramethylbutyl)phenol); SCCS/1460/11; Scientific Committee on Consumer Safety: Brussels, Belgium, 2011. Available online: https:/ /op.europa.eu/en/publication-detail/-/publication/ 09dcfef6-40cf-4d37-b787-13a13996fcd9 (accessed on 15 July 2021).

118. SCCS. Opinion on 2,2'-Methylene-bis-(6-(2H-benzotriazol-2-yl)-4-(1,1,3,3-tetramethylbutyl)phenol) (Nano Form); SCCS/1546/15; Scientific Committee on Consumer Safety: Brussels, Belgium, 2015. Available online: https://op.europa.eu/en/publication-detail/-/ publication/ad2cb4e2-063d-11e8-b8f5-01aa75ed71a1 (accessed on 15 July 2021).

119. SCCS. Opinion on 1,3,5-Triazine, 2,4,6-tris[1,1'-biphenyl]-4-yl-; SCCS/1429/11; Scientific Committee on Consumer Safety: Brussels, Belgium, 2011. Available online: https:/ / ec.europa.eu/health/scientific_committees/consumer_safety/docs/sccs_o_070.pdf (accessed on 15 July 2021).

120. SCCS. Opinion on Carbon Black (Nano Form); SCCS/1515/13; Scientific Committee on Consumer Safety: Brussels, Belgium, 2013. Available online: https:/ / op.europa.eu/en/publication-detail/-/publication/400c8d18-e67b-46b5-aee5-2bf344955e05 (accessed on 15 July 2021).

121. SCCS. Opinion on Hydroxyapatite (Nano); SCCS/1566/15; Scientific Committee on Consumer Safety: Brussels, Belgium, 2015. Available online: https:/ / op.europa.eu/en/publication-detail/-/publication/56b33f4f-0256-11e7-8a35-01aa75ed71a1 (accessed on 15 July 2021).

122. SCCS. Opinion on Hydroxyl-Apatite (Nano); SCCS/1624/20; Scientific Committee on Consumer Safety: Brussels, Belgium, 2020. Available online: https:/ / ec.europa.eu/health/sites/default/files/scientific_committees/consumer_safety/docs/sccs_o_246.pdf (accessed on 20 August 2021).

123. SCCS. Opinion on Colloidal Silver (Nano); SCCS/1596/18; Scientific Committee on Consumer Safety: Brussels, Belgium, 2018. Available online: https:/ /op.europa.eu/it/publication-detail/-/publication/654c48ce-38cd-11e9-8d04-01aa75ed71a1 (accessed on 15 July 2021). 
124. SCCS. Opinion on Silica, Hydrated Silica, and Silica Surface Modified with Alkyl Silylates (Nano Form); SCCS/1545/15; Scientific Committee on Consumer Safety: Brussels, Belgium, 2015. Available online: https://op.europa.eu/it/publication-detail/-/ publication/7e9e28a6-d3af-11e5-a4b5-01aa75ed71a1 (accessed on 15 July 2021).

125. SCCS. Opinion on Solubility of Synthetic Amorphous Silica (SAS); SCCS/1606/19; Scientific Committee on Consumer Safety: Brussels, Belgium, 2019. Available online: https:/ / ec.europa.eu/health/sites/default/files/scientific_committees/consumer_safety/docs/ sccs_o_228.pdf (accessed on 15 July 2021).

126. SCCS. Opinion on Styrene/Acrylates Copolymer (Nano) and Sodium Styrene/Acrylates Copolymer (Nano); SCCS/1595/18; Scientific Committee on Consumer Safety: Brussels, Belgium, 2018. Available online: https://ec.europa.eu/health/sites/default/files/ scientific_committees/consumer_safety/docs/sccs_o_218.pdf (accessed on 15 July 2021).

127. SCCS. Preliminary Opinion on Copper (Nano) and Colloidal Copper (Nano); SCCS/1621/20; Scientific Committee on Consumer Safety: Brussels, Belgium, 2020. Available online: https:/ / ec.europa.eu/health/sites/health/files/scientific_committees/consumer_ safety/docs/sccs_o_245.pdf (accessed on 15 July 2021).

128. Doak, S.H. Opinion of the Scientific Committee on consumer safety (SCCS)-Opinion on the use of 2,20-methylene-bis(6-(2H-benzotriazol-2-yl)- 4-(1,1,3,3-tetramethylbutyl)phenol) (nano)—S79-In cosmetic products. Front. Chem. 2016, 76, 215-216. [CrossRef]

129. Chaudhry, Q. Opinion of the Scientific Committee on Consumer safety (SCCS)—Second revision of the opinion on carbon black, nano-form, in cosmetic products. Regul. Toxicol. Pharmacol. 2016, 79, 103-104. [CrossRef] [PubMed]

130. Bernauerb, U. Opinion of the Scientific Committee on Consumer Safety (SCCS)—Revision of the Opinion on hydroxyapatite (nano) in cosmetic products. Regul. Toxicol. Pharmacol. 2018, 98, 274-275. [CrossRef] [PubMed] 